OPEN ACCESS

Edited by:

Kette D. Valente,

Universidade de São Paulo, Brazil

Reviewed by:

David Ruskin,

Trinity College, United States

Katia Lin,

Federal University of Santa

Catarina, Brazil

*Correspondence:

Moisés Rubio-Osornio

ruomon@gmail.com

Specialty section:

This article was submitted to

Epilepsy,

a section of the journa

Frontiers in Neurology

Received: 19 July 2020 Accepted: 28 September 2020 Published: 05 November 2020

Citation:

Rubio C, Luna R, Rosiles $A$ and Rubio-Osornio M (2020) Caloric

Restriction and Ketogenic Diet

Therapy for Epilepsy: A Molecular Approach Involving Wnt Pathway and

$K_{\text {ATP }}$ Channels.

Front. Neurol. 11:584298. doi: 10.3389/fneur.2020.584298

\section{Caloric Restriction and Ketogenic Diet Therapy for Epilepsy: A Molecular Approach Involving Wnt Pathway and $\mathrm{K}_{\mathrm{ATP}}$ Channels}

\author{
Carmen Rubio ${ }^{1}$, Rudy Luna ${ }^{1}$, Artemio Rosiles ${ }^{2}$ and Moisés Rubio-Osornio ${ }^{2 *}$ \\ ${ }^{1}$ Neurophysiology Department, National Institute of Neurology and Neurosurgery, Manuel Velasco Suárez, Mexico City, \\ Mexico, ${ }^{2}$ Experimental Laboratory of Neurodegenerative Diseases, National Institute of Neurology and Neurosurgery, Manuel \\ Velasco Suárez, Mexico City, Mexico
}

Epilepsy is a neurological disorder in which, in many cases, there is poor pharmacological control of seizures. Nevertheless, it may respond beneficially to alternative treatments such as dietary therapy, like the ketogenic diet or caloric restriction. One of the mechanisms of these diets is to produce a hyperpolarization mediated by the adenosine triphosphate (ATP)-sensitive potassium (K $\mathrm{K}_{\text {ATP }}$ ) channels (K $\mathrm{K}_{\text {ATP }}$ channels). An extracellular increase of $\mathrm{K}^{+}$prevents the release of $\mathrm{Ca}^{2+}$ by inhibiting the signaling of the Wnt pathway and the translocation of $\beta$-catenin to the cell nucleus. Wnt ligands hyperpolarize the cells by activating $\mathrm{K}^{+}$current by $\mathrm{Ca}^{2+}$. Each of the diets described in this paper has in common a lower use of carbohydrates, which leads to biochemical, genetic processes presumed to be involved in the reduction of epileptic seizures. Currently, there is not much information about the genetic processes implicated as well as the possible beneficial effects of diet therapy on epilepsy. In this review, we aim to describe some of the possible genes involved in Wnt pathways, their regulation through the $\mathrm{K}_{\text {ATP }}$ channels which are implicated in each one of the diets, and how they can reduce epileptic seizures at the molecular level.

Keywords: epilepsy, ketogenic diet, caloric restriction, $\mathrm{K}_{\text {ATP }}$ channels, Wnt

\section{INTRODUCTION}

Epilepsy, despite having a large number of different treatments, is actually one of the diseases with poor control of epileptic seizures. This is because of the lack of understanding of epileptogenesis, seizure genesis, seizure spread, and seizure suppression (1). Approximately $30 \%$ of patients have refractory epilepsy, which means that adequate trials of at least two drug programs have failed $(2,3)$. Drug treatment is usually aimed at having a neuronal anti-glutamatergic effect or demands the actions of GABA; some anti-epileptics act on ion channels of calcium, sodium, or potassium, stabilizing the neuronal membranes and thus avoiding the synchronization and the propagation of abnormal discharges. An alternative to counteract epileptic seizures is surgery, but just a selected number of patients are candidates for this type of treatment. These are the many reasons why it is necessary to look for alternative therapies for seizure control (4).

Neuronal activity is closely related to the metabolism of carbohydrates that influence neuronal excitability, which can become abnormal as it happens in epilepsy. Carbohydrates promote the production of fatty acids for the generation of ketone bodies. Animal experiments have provided evidence that the anticonvulsant effect of the ketogenic diet (KD) is mediated by acetone, which 


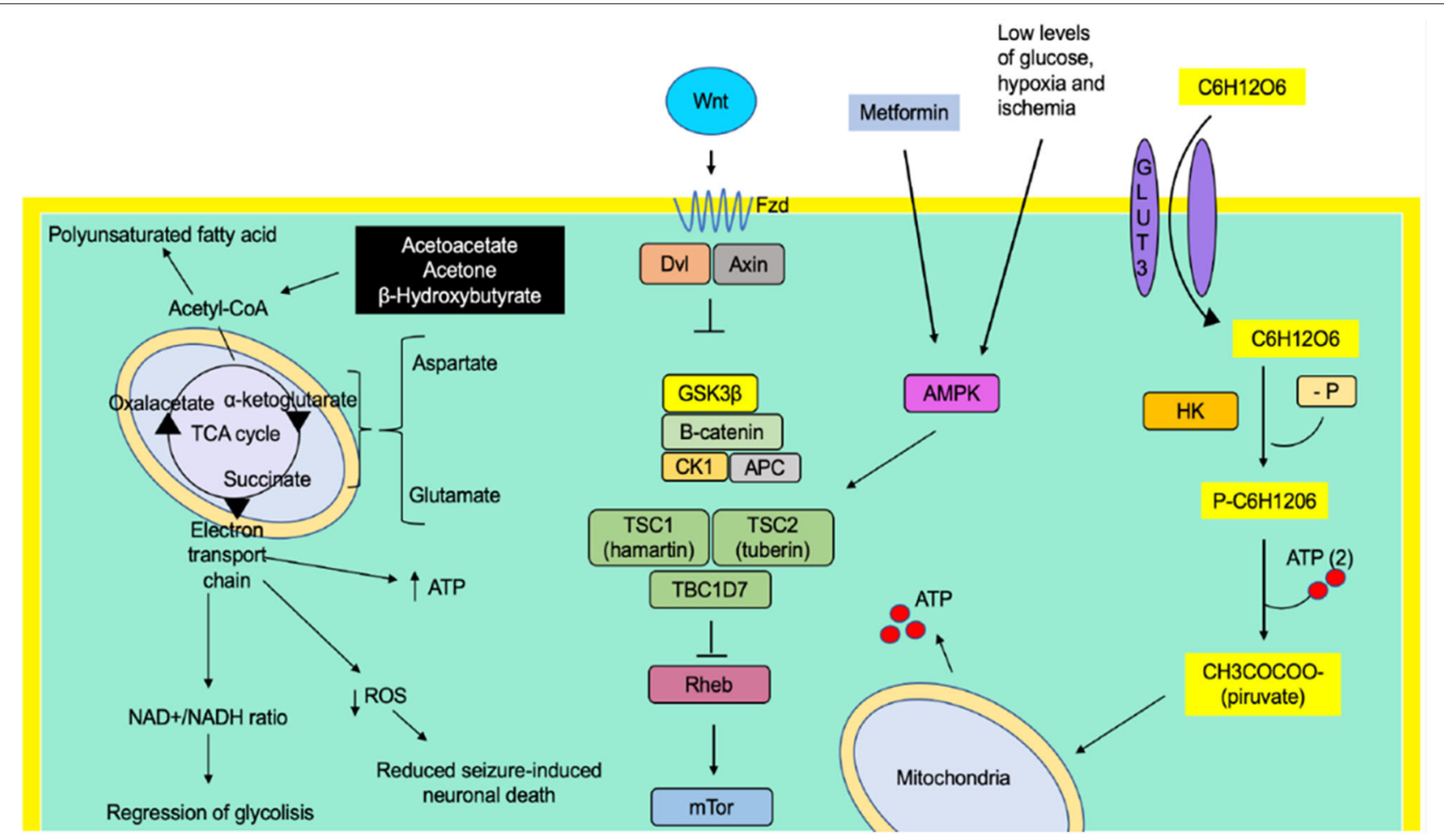

GRAPHICAL ABSTRACT| The ketogenic diet has shown a decrease in seizures through the production of ketone bodies that cause an effect on neuronal function and the release of neurotransmitters, such as a decrease of glutamate, and adenosine, mitochondrial function, increase of GABA synthesis, and KATP channels. Caloric restriction may inhibit glycolysis and, just like the ketogenic diet, is involved in mitochondrial biogenesis, decreased oxidative stress, and decreasing inflammation, but it appears that it does not have an ionic gradient effect on $\mathrm{K}_{\text {ATP }}$ channels. The ketogenic diet and caloric restriction per se down-regulated and up-regulated some genes involved in seizure activity.

has shown efficacy in the treatment of epilepsy, though it is not the only mechanism described (5). Glucose is the main substrate for obtaining energy in adult brains. Approximately 63\% of glucose supplies is estimated to be used to obtain energy in a 7-days-old rat's brain; this amount increases with age (6).

Since 1921, dietary therapies have been suggested to have an important role in epileptic seizure control, including infantile spasms, Doose syndrome, Rett syndrome, tuberous sclerosis, Dravet syndrome $(7,8)$, and other neurological diseases. Seizure control is obtained by different mechanisms. What they all have in common is an overall reduction in glucose levels, elevated free fatty acids, and ketone levels (9). Thus, dietary therapy may play a role in slowing down the progression of a specific disorder (10).

The Wnt signaling pathway is actively involved in glucose regulation pathways, especially by increasing glucose absorption in cortical neurons independently of the activation of target genes and the synaptic effect of Wnt (11). In recent years, attempts have been made to describe the participation of adenosine triphosphate (ATP)-sensitive potassium $\left(\mathrm{K}_{\mathrm{ATP}}\right)$ channels $\left(\mathrm{K}_{\mathrm{ATP}}\right.$ channels) as a convergent mechanism of the effect that restrictive diets provide, because of a reduction in glycolytic pathways and the increase of ketone bodies, and therefore a cellular excitability reduction by lowering cytoplasmic ATP and activating the $\mathrm{K}_{\mathrm{ATP}}$ channels. Therefore, the $\mathrm{K}_{\mathrm{ATP}}$ channels rather than closed by ketone bodies could be activated, generating an output of positive ions and decreasing neuronal excitability (12). The association of the neuronal excitability is gaining importance, which depends mostly on these $\mathrm{K}_{\mathrm{ATP}}$ channels and the Wnt pathways, though a clear relationship with glycolytic pathways and their metabolic regulation remain to be clarified.

Therefore, the objective throughout this review is to describe the Wnt pathway as a regulator of the $\mathrm{K}_{\mathrm{ATP}}$ channels involved in the ketogenic diet and caloric restriction as well as to point out the possible genes involved in each of the diets and how they can molecularly achieve a reduction in epileptic seizures (Tables 1 and 2). To accomplish our objective, we have looked into articles concerning restrictive diet therapy, their multiple and different mechanisms of action involving cellular metabolism, molecular signaling, and gene interaction, all associated with epileptogenesis in experimental and clinical research. In the gene tables below, we looked for the authors who firstly reported these genes in literature and for the authors that associated them with diet therapy, Wnt signaling pathway, epileptogenesis, and $\mathrm{K}_{\text {ATP }}$ channels.

\section{CALORIC RESTRICTION}

Caloric restriction (CR) is described to be a natural dietary therapy that improves health, prolongs longevity, and reduces 
TABLE 1 | Down and up regulated genes implicated in the Wnt and mTor signaling pathway after caloric restriction therapy.

Gene Action References

\section{Down-regulated genes due to caloric restriction}

akt1

apc

$\operatorname{axin} 1$

csnk1a1l

ctnnb1

cyclin d1

gsk3 $\beta$

c-myc

ngr1

wnt5a

\section{Up-regulated genes due to caloric restriction}

ctnnb1

$d v 11$

fzd1

Irp5 stabilization. GSK3B. phosphorylation.

to caloric restriction WNT3A signaling.
AKT protein participates in the increase of glucose, inducing glycogen synthesis due to the inhibition of GKS3B in rapamycin proteins AKT regulates the storage of glucose in the form of glycogen by phosphorylating GSK3A at "Ser-21" and GSK3B at "Ser-9," resulting in inhibition of its kinase activity. Phosphorylation of GSK3 isoforms by AKT is thought to be one mechanism by which cell proliferation is driven. AKT mediates insulin-stimulated protein synthesis by phosphorylating TSC2 at "Ser-939" and "Thr-1462," thereby activating mTORC1 signaling and leading to both phosphorylation of 4E-BP1 and activation of RPS6KB1.

Promotes the rapid degradation of CTNNB1 and participates in Wnt signaling as a negative regulator. APC activity is correlated with its phosphorylation state. Activates the GEF activity of SPATA13 and ARHGEF4. Plays a role in Hepatocyte growth factor (HGF)-induced cell migration. It is required for MMP9 up-regulation via the JNK signaling pathway in colorectal tumor cells. Acts as a mediator of ERBB2-dependent stabilization of microtubules at the cell cortex. It is needed for the localization of MACF1 to the cell membrane which is critical for its function in microtubule

This gene encodes a cytoplasmic protein which contains a regulation of G-protein signaling (RGS) domain and a disheveled and axin (DIX) domain. In Wnt signaling, probably facilitates the phosphorylation of CTNNB1 and APC by

Casein Kinase 1 Alpha 1 Like, is a protein-coding gene. It can phosphorylate a large number of proteins. It participates in Wnt signaling. In the absence of Frizzled (Fzd) receptor stimulation by Wnt, the proteins Axin and APC promote

Beta-catenin protein is an integral part of the canonical Wnt signaling pathway. Wht binding to Fzd receptors and LRP co-receptors activates Disheveled (Dsh) proteins; these in exchange inhibit the destruction complex responsible for degrading beta-catenin, which includes GSK3.

Cyclins function as regulators of CDK kinases. The Wnt canonical pathway ( $\beta$-catenin-dependent signaling pathway) has been implicated in leading to the regulation of transcriptional activity and activation of c-Myc and cyclin D. The overexpression effect of $\beta$-catenin on c-Myc and cyclin D causes neuronal death found in Purkinje cells and granule layer of the cerebellum of rats with repeated generalized seizures. It exerts the apoptotic effect through positive regulation and activation of proapoptotic proteins.

It is a negative regulator of glucose homeostasis and is involved in energy metabolism, inflammation, ER-stress, mitochondrial dysfunction, and apoptotic pathways. In Wnt signaling, GSK3 $\beta$ forms a multimeric complex with APC, AXIN1, and CTNNB1/ $\beta$-catenin and phosphorylates the $N$ - terminus of CTNNB1 leading to its degradation mediated by ubiquitin/proteasomes.

This gene is a proto-oncogene and encodes a nuclear phosphoprotein that plays a role in cell cycle progression, apoptosis and cellular transformation. The Wnt canonical pathway ( $\beta$-catenin-dependent signaling pathway) has been implicated in leading to the regulation of transcriptional activity and activation of c-Myc and cyclin D. The overexpression effect of $\beta$-catenin on c-Myc and cyclin D cause neuronal death found in Purkinje cells and granule layer of the cerebellum of rats with repeated generalized seizures. It exerts the apoptotic effect through positive regulation and proapoptotic proteins activation.

It up-regulates mRNA levels of $\beta$-catenin, Dvl, and Fzd proteins. It increases spontaneous firing rates in hippocampal pyramidal neurons, increasing membrane excitability without affecting resting membrane potential nor action potential amplitude. Decreases sustained $\mathrm{K}^{+}$currents in hippocampal neurons.

This gene encodes a member of the Wnt family that signals through both the canonical and non-canonical WNT pathways. In the presence of ROR2, inhibits the canonical Wnt pathway by promoting $\beta$-catenin degradation through a GSK3-independent pathway, which involves down-regulation of $\beta$-catenin-induced reporter gene expression. co-receptors activates Dsh proteins; these in exchange inhibit the destruction complex responsible for degrading $\beta$-catenin, which includes GSK3. Participates in Wnt signaling by binding to the cytoplasmic C- terminus of Fzd family members and transducing the Wnt signal to down-stream effectors. It plays a role both in canonical and non-canonical Wnt signaling, as well as in the signal transduction pathways mediated by multiple Wnt genes. It is required for LEF1 activation upon WNT1 and Members of the "frizzled" gene family encode 7-transmembrane domain proteins that are receptors for Wnt signaling proteins. Activated by WNT3A, WNT3, WNT1, and to a lesser extent WNT2. The canonical Wnt/ $\beta$-catenin signaling pathway leads to the activation of disheveled proteins, inhibition of GSK3 kinase, nuclear accumulation of $\beta$-catenin, and activation of Wht target genes.

55
This gene encodes a transmembrane low-density lipoprotein receptor that binds and internalizes ligands in the process of receptor-mediated endocytosis. This protein also acts as a co-receptor with Fzd protein family members for transducing signals by Wht proteins.
$(13,14)$

$(15-17)$

$(18-21)$. 


\begin{tabular}{|c|c|c|}
\hline slc2a3/glut3 & $\begin{array}{l}\text { Wnt3A increase GLUT3 in its affinity by stimulating two glycolysis regulatory enzymes (hexokinase enzyme and 6- } \\
\text { phosphofruct-2-kinase/fructose-2,3-bisphosphatase) directly correlated with the increase in glucose absorption. }\end{array}$ & $(11,35)$ \\
\hline wnt1 & $\begin{array}{l}\text { This gene is a member of the Wnt gene family. Acts in the canonical Wnt signaling pathway by promoting } \beta \text {-catenin- } \\
\text { dependent transcriptional activation. It plays an essential role in the development of the embryonic brain and central } \\
\text { nervous system. }\end{array}$ & $(18,19,37)$ \\
\hline wnt10b & $\begin{array}{l}\text { This gene is a member of the Wnt gene family. It specifically activates the canonical Wnt/ } \beta \text {-catenin signaling and thus } \\
\text { triggers } \beta \text {-catenin/LEF/TCF-mediated transcriptional programs. Involved in signaling networks controlling stemness, } \\
\text { pluripotency, and cell fate decisions. }\end{array}$ & $(18,19,38)$ \\
\hline wnt7a & $\begin{array}{l}\text { This gene is a member of the Wnt gene family. Required for normal progress through the cell cycle in neural progenitor } \\
\text { cells, for self-renewal of neural stem cells, and normal neuronal differentiation and maturation. Promotes formation of } \\
\text { synapses via its interaction with Fzd5 }\end{array}$ & $(22,30)$ \\
\hline
\end{tabular}

Description of every gene function and how molecularly can decrease seizures for a better understanding of epileptogenesis and future ideas for an anticonvulsant therapy.

the effects of new inflammatory diseases in rodents and humans (77-79). CR occurs by partial dietary restriction and differs from acute fasting or starvation. CR reduces caloric energy consumption without causing eating disorders or any specific nutrient deficiency (80). In addition to improving health status, $\mathrm{CR}$ has anticonvulsant effects in murine and other epilepsy models $(81,82)$.

Moreover, it is proposed that the anti-epileptic action of CR may require a reduction in glucose or insulin concentrations and an increase in the $\beta$-hydroxybutyrate $(\beta-\mathrm{HB})$ ketone body (83), along with increased fatty acid oxidation and reduced lipid accumulation in some tissues, as CR has been strongly related with improving insulin sensitivity and increasing adiponectin levels (84). Electrographically, CR has shown an increase in the neuron discharge threshold, providing an anti-epileptic effect (85). Also, CR in rats with epilepsy induction by the Kindling model increased the threshold after a stimulus applied to the amygdala and showed a decreased duration of epileptic activity (86). The abovementioned finding suggests that CR carries an anti-seizure profile and is completely independent of changes in glucose, insulin, or $\beta$-HB (82).

Talevi and Rocha (9) mention that CR may inhibit glycolysis and, just like the $\mathrm{KD}$, is involved in mitochondrial biogenesis and decreases oxidative stress and inflammation, but it appears that it does not have an ionic gradient effect on the $\mathrm{K}_{\mathrm{ATP}}$ channels. However, according to Kawamura et al. (87) in 2010, in neurons from CA3 of the hippocampus after $\mathrm{CR}$ and the ketogenic diet, the glucose levels decreased and provoked an increase of ATP after opening $\mathrm{K}^{+}$channels, lowering neural excitability and stabilizing the membrane. After $\mathrm{CR}$ in rats, a reduction in the degeneration of GABAergic neurons in the hippocampus and the entorhinal cortex was shown before the administration of kainic acid (88).

\section{Physiological Effects of Caloric Restriction on Wnt/B-Catenin on the Brain}

New signaling pathways have been postulated on the effects of caloric restriction in the brain, one of them involving glycolytic metabolism in neurons, but little is known about the intervention of the $W n t / \beta$-catenin pathway $(89,90)$. The brain is an organ that consumes large amounts of glucose. In brain tissue, glucose is oxidized by glycolysis and oxidative phosphorylation to produce ATP, the product with the highest consumption by the neuron during the formation of the ionic gradient after synaptic transmission $(91,92)$.

The stimulation of cortical neurons with Wnt3a stimulates glucose absorption without significant changes in the expression and the functionality of glucose transporter 3 (GLUT3), but with an increase in its affinity. Furthermore, by stimulating the same ligand, the activity of two glycolysis regulatory enzymes (hexokinase enzyme and 6-phosphofruct-2-kinase/fructose-2,3bisphosphatase) increases, as they are correlated directly with the increase in glucose absorption (11) (Figure 1). Besides the Wnt pathway, AKT participates in the glucose increase by inducing glycogen synthesis due to the inhibition of 3-kinaseglycogen synthase in rapamycin proteins $(93,94)$. Alterations in the $W n t / \beta$-catenin signaling pathways have also been identified, generating mutations in genes involved in gluconeogenesis and glutamine metabolism in hepatocytes. Many of these proteins involved are associated with mitochondrial dysfunction and carbohydrate metabolism, suggesting that having defects in Wnt 
TABLE 2 | Down and up regulated genes implicated in the Wnt signaling pathway and pxidative stress after ketogenic diet therapy.

\begin{tabular}{|c|c|c|}
\hline Gene & Action & References \\
\hline \multicolumn{3}{|c|}{ Down-regulated genes due to ketogenic diet } \\
\hline armcx3/ alex3 & $\begin{array}{l}\text { Its overexpression produces mitochondrial alterations. Mitochondrial distribution and dynamics are regulated through } \\
\text { ARMCX } 3 \text { protein degradation, which is promoted by PCK and negatively regulated by WNT1. Wht regulates } \\
\text { mitochondrial distribution and dynamics through the degradation of the Armcx3 protein. }\end{array}$ & $(40,41)$ \\
\hline gabra4 & $\begin{array}{l}\text { This gene encodes subunit alpha-4, which is involved in the etiology of autism and eventually increases the risk of } \\
\text { Status Epilepticus and Autism. }\end{array}$ & $(42,43)$ \\
\hline mct 2/slc16a7 & $\begin{array}{l}\text { The protein encoded by this gene catalyzes the proton- linked transport of monocarboxylates and has the highest } \\
\text { affinity for pyruvate. This protein has been reported to be more highly expressed in prostate and colorectal cancer } \\
\text { specimens when compared to control specimens. }\end{array}$ & $(46,47)$ \\
\hline mct 4/slc16a3 & $\begin{array}{l}\text { Lactic acid and pyruvate transport across plasma membranes is catalyzed by members of the proton-linked } \\
\text { monocarboxylate transporter (MCT) family, which has been appointed solute carrier family-16. }\end{array}$ & $(47,48)$ \\
\hline snap25 & This gene product is a presynaptic plasma membrane protein involved in the regulation of neurotransmitter release. & $(42,51)$ \\
\hline \multicolumn{3}{|c|}{ Up-regulated genes due to ketogenic diet } \\
\hline atp $5 \mathrm{c} 1$ & $\begin{array}{l}\text { Catalyzes ATP synthesis, utilizing an electrochemical gradient of protons across the inner membrane during oxidative } \\
\text { phosphorylation. }\end{array}$ & $(10,52)$ \\
\hline atp5d & $\begin{array}{l}\text { Catalyzes ATP synthesis, utilizing an electrochemical gradient of protons across the inner membrane during oxidative } \\
\text { phosphorylation. }\end{array}$ & $(10,53)$ \\
\hline atp5po & $\begin{array}{l}\text { Component of the F-type ATPase found in the mitochondrial matrix. F-type ATPases are composed of a catalytic core } \\
\text { and a membrane proton channel. }\end{array}$ & $(10,54)$ \\
\hline atp6v1f & $\begin{array}{l}\text { Encodes a component of vacuolar ATPase (V-ATPase), a multisubunit enzyme that mediates acidification of eukaryotic } \\
\text { intracellular organelles. This encoded protein is the V1 domain F subunit protein. }\end{array}$ & $(10,55)$ \\
\hline atpaf2 & $\begin{array}{l}\text { Encodes an assembly factor for the } \mathrm{F}(1) \text { component of the mitochondrial ATP synthase. This protein binds specifically } \\
\text { to the } \mathrm{F} 1 \text { alpha subunit and is thought to prevent this subunit from forming nonproductive homo-oligomers during } \\
\text { enzyme assembly. }\end{array}$ & $(10,56)$ \\
\hline idh2 & $\begin{array}{l}\text { Exhibits isocitrate dehydrogenase (NADP+) activity. Involved in NADP biosynthetic process; negative regulation of } \\
\text { gliogenesis, and negative regulation of matrix metallopeptidase secretion. Predicted to localize to the cytosol, } \\
\text { mitochondrion, and peroxisome. }\end{array}$ & $(10,63)$ \\
\hline idh3g & $\begin{array}{l}\text { Isocitrate dehydrogenases catalyze the oxidative decarboxylation of isocitrate to 2-oxoglutarate. These enzymes } \\
\text { belong to two distinct subclasses, one of which utilizes } N A D(+) \text { as the electron acceptor and the other } N A D P(+) \text {. }\end{array}$ & $(10,64)$ \\
\hline irs 1 & $\begin{array}{l}\text { The insulin receptor substrate } 1 \text { signaling protein (IRS-1) induces a transcriptional effect of Wnt. The higher level of } \\
\text { IRS-1 drives the activation of mitochondrial biogenesis. Furthermore, in insulin-sensitive cell types, it improves insulin } \\
\text { signaling, raising the possibility that } W n t \text { proteins can be used to modulate glucose homeostasis. }\end{array}$ & $(65,66)$ \\
\hline mct1/ slc16a1 & $\begin{array}{l}\text { Ion transport channels: catalyzes the movement of many monocarboxylates, such as lactate and pyruvate, across the } \\
\text { plasma membrane. }\end{array}$ & $(42,67)$ \\
\hline mdh1 & $\begin{array}{l}\text { This gene encodes an enzyme that catalyzes the NAD/NADH-dependent, reversible oxidation of malate to } \\
\text { oxaloacetate in many metabolic pathways, including the citric acid cycle. }\end{array}$ & $(10,68)$ \\
\hline mah2 & $\begin{array}{l}\text { The protein encoded by this gene is localized to the mitochondria and may play pivotal roles in the malate- aspartate } \\
\text { shuttle that operates in the metabolic coordination between cytosol and mitochondria. }\end{array}$ & $(10,68)$ \\
\hline ndufa6 & $\begin{array}{l}\text { The encoded protein is an accessory subunit of NADH: ubiquinone oxidoreductase (Complex I), which is the largest } \\
\text { enzyme of the mitochondrial membrane respiratory chain. Complex I function in electron transfer from NADH to the } \\
\text { respiratory chain. }\end{array}$ & $(10,69)$ \\
\hline
\end{tabular}




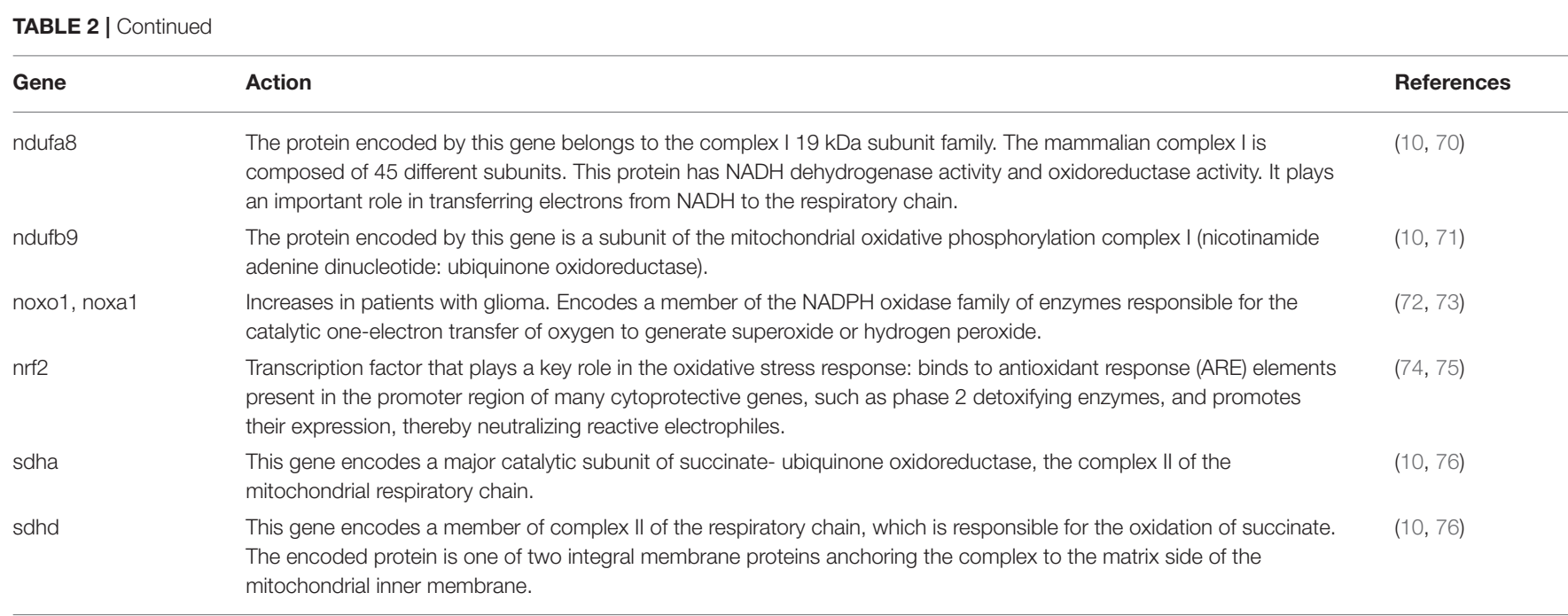

Description of every gene function and how molecularly can decrease seizures for a better understanding of epileptogenesis and future ideas for an anticonvulsant therapy.

signaling may also determine a metabolic change in the energy utilization of cells toward glycolysis and staying away from fatty acid oxidation (95). The intervention of $W n t / \beta$-catenin signaling pathways in glycolytic pathways and their indirect role in the cell membrane activity of epileptic neurons are still not fully understood. Wnt signaling pathways are essential for the development and the function of the central nervous system because it modulates key processes such as hippocampal neurogenesis, synaptic cleft formation, and mitochondrial regulation $(96,97)$. The insulin receptor substrate 1 signaling protein (IRS-1) induces a transcriptional effect of Wnt. The higher level of IRS-1 drives the activation of mitochondrial biogenesis. Moreover, in insulin-sensitive cell types, it improves insulin signaling, again raising the possibility that $W n t$ proteins can be utilized to modulate glucose homeostasis (65).

\section{Wnt Pathways}

Wnt signals can be divided into two main pathways: the canonical pathway ( $\beta$-catenin-dependent signaling pathway) and the non-canonical pathway ( $\beta$-catenin-independent). The first has been implicated in leading the regulation of transcriptional activity and the activation of genes such as c-Myc, cyclin D, and the TCF/LEF (T-cell factor/lymphoid promoter-binding factor) pathway that determines cell fate such as determination, proliferation, and differentiation of stem cells. The binding of a specific Wnt (such as Wnt1, Wnt10b, or Wnt3A) to their Fzd (Frizzled)-LRP5 or Fzd-LRP6 receptors results in the activation of intracellular heterotrimeric G proteins and Dvl (Disheveled) proteins, which in the dentate gyrus leads to phosphorylation and recruitment of Axin to LRP5 (or LRP6) and participating as a co-receptor $(18,19,98)$. The abovementioned event leads to the dissociation of $\beta$-catenin and the degradation complex by promoting its stabilization and the accumulation of the molecule in the cytosol. Thus, it is translocated toward the nucleus and activates the transcription factors of the TCF/LEF families $(21,99)$, c-Myc, and cyclin D. Certain intracellular molecules expressed by $W n t$-dependent activation of $\beta$-catenin jointly participate in the pyramidal cells of the region hippocampal CA1 and can increase the sensitivity to pentylenetetrazole and kainate by inducing seizures and cell death (100). The opened $\mathrm{K}_{\mathrm{ATP}}$ channels produce ROS due to gene triggering, which increases mitochondrial production. The block of $\mathrm{K}_{\mathrm{ATP}}$ channels induces the release of $\mathrm{Ca}^{2+}$ in the nucleus, leading to the expression of the c-myc gene (101). In 2008, Jeon et al. (102) reported that 10 repeated electroconvulsive seizures in the rat's brain exert a neuroprotective effect on the inhibition of c-Myc protein levels and subsequent inactivation of the Bad proapoptotic protein while allowing the activation of BclXL. However, the overexpression effect of $\beta$-catenin on c-Myc and cyclin D causes neuronal death in Purkinje cells and the granule layer of the cerebellum of rats with repeated generalized seizures. Activation of $\beta$-catenin can induce the overexpression of $\mathrm{c}-\mathrm{Myc}$ and cyclin $\mathrm{D}$ that exert an apoptotic effect through positive regulation and activation of proapoptotic proteins (103). The voltage-gated calcium channel $\beta 4$ subunit inhibits cyclin-D1, which prevents the activity by $\beta$-catenin due to an interaction with TCF4 and controlling different transcription factors (104).

The second Wnt-dependent or non-canonical pathway has been preferentially implicated in cell movement $(105,106)$. This pathway alters intracellular $\mathrm{Ca}^{2+}$ activated by $W n t 5 \mathrm{a}$ and simultaneously decreases potassium currents, leading to an increase in neuronal excitability, specifically in CA1 pyramidal neurons (107). The activation of Fzd receptors by its Wnt ligand induces the inhibition of the enzyme GSK3 $\beta$, which generates the activation of tuberin protein (TSC2) (15). Without these signals, TSC2 inhibits the brain protein-enriched homologous Ras protein (Rheb), an activator of mTORC1 (108). Thus, inactivation of Rheb by TSC2 leads to the inhibition of mTORC1, and inhibition of TSC2 leads to the indirect activation of mTORC1.

Recently, our research group reported that mild CR (15\%) significantly increased the phosphorylation of protein kinase activated by adenosine monophosphate (AMPK) (Figure 2). Furthermore, it reduces the phosphorylation of 


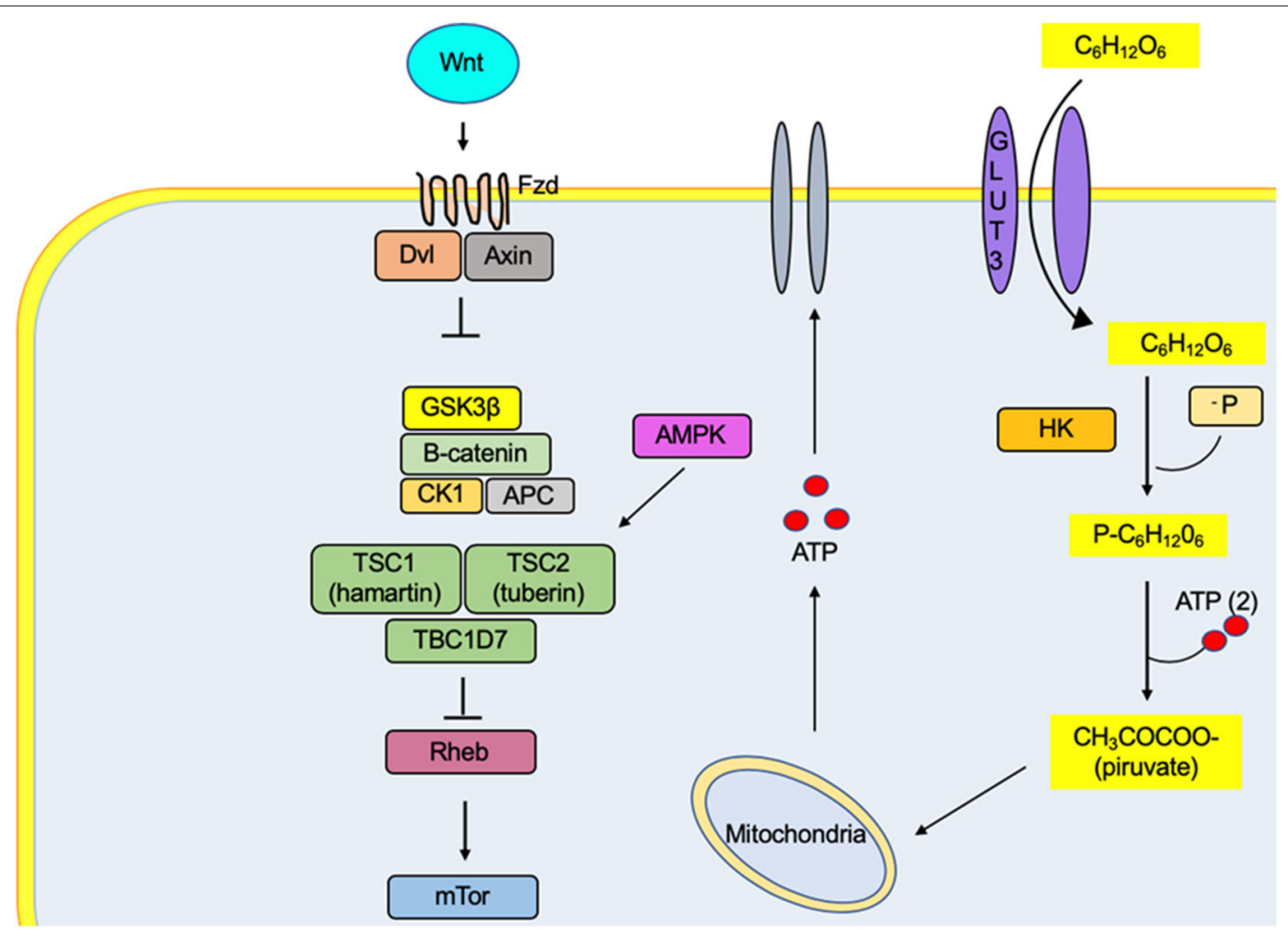

FIGURE 1 | The metabolic effect of Wnt promotes the absorption of glucose in the neuron by increasing the affinity of the GLUT3 transporter for its substrate. In the same way, it increases the activity of the enzyme hexokinase, one of the proteins regulating the glycolytic rate. Therefore, there is an increase in the ATP concentrations, a metabolic substrate for the regulation of channels responsible for the excitability of the cell membrane. The activation of the Fzd receptors by its Wnt ligand causes the decoupling of $\beta$-catenin degradation complex (GSK3 $\beta$, CK1, APC, and $\beta$-catenin proteins), preventing their degradation by the proteasome and generating an accumulation in the cytosol and its translocation to the nucleus, where it binds to T-cell factor/lymphoid-enhancer binding factor family transcription factors, thus promoting the transcription of genes related to lipid metabolism and cell differentiation, among others.

ribosomal protein (S6) and $\mathrm{PKB} / \mathrm{Akt}$ in the neocortex and the hippocampus, suggesting that mild CR inhibits mTORC1 signaling pathways. Therefore, an effect of raising the discharge threshold potential has been pointed out, suggesting an anticonvulsant action (82).

It is a fact that due to the glycolytic regulation of CR, this diet gets involved in the Wnt signaling pathway. We suggest that the resulting proteins of this pathway are part of seizure pathogenesis in experimental models, proposing that CR could help in seizure control through the proteins of the Wnt signaling pathway. Nevertheless, further research needs to be done to understand this mechanism and suggest a specific molecular/genetic target for therapeutic intervention.

\section{The Effects of Caloric Restriction in the mTOR Signaling Pathway}

One of the Wnt functions is to increase gene expression through the transcriptional activity of $\beta$-catenin, as well as protein synthesis through the mammalian target of rapamycin (mTOR). However, their interaction is not completely understood. Caloric restriction reduces the epileptic activity inhibiting the mTOR signaling pathway. This is a main pathophysiology component of epileptic seizure (109). The hyperactivation of mTOR participates in epilepsy; the inhibition on this kinase results in beneficial anti-convulsive effects. It is related to cell proliferation, protein synthesis, cell survival, angiogenesis, apoptosis, and cell motility.

mTOR is divided into two complexes, mTORC1, implicated in cell growth and proliferation as well as metabolism, and mTORC2, involved in the regulation of protein kinases and the cytoskeletal elements of the cell (110). Mutations in the mTOR pathway are associated with dysplasias, epilepsy, and neurodevelopmental disorders like tuberous sclerosis complex, Cowden's syndrome, polyhydramnios, megalencephaly, and neurofibromatosis type 1 (111).

The TOR protein family plays a role in regulating mRNA transcription initiation and protein translation in response to intracellular concentrations of amino acids and other essential nutrients. The mTOR pathway is activated by ingestion, rising from blood glucose levels, which consequently increases insulin. Excess protein in the diet stimulates the mTOR pathway, phosphorylating the insulin receptor, among others, while generating more insulin, which can aggravate the Ser/Thr phosphorylation of the insulin receptor through mTORC1 activation. mTORC1 activation suppresses Wnt canonical pathway expression and regulates Fzd and Dvl for stem cell functioning and cellular homeostasis (112). As mentioned before, 


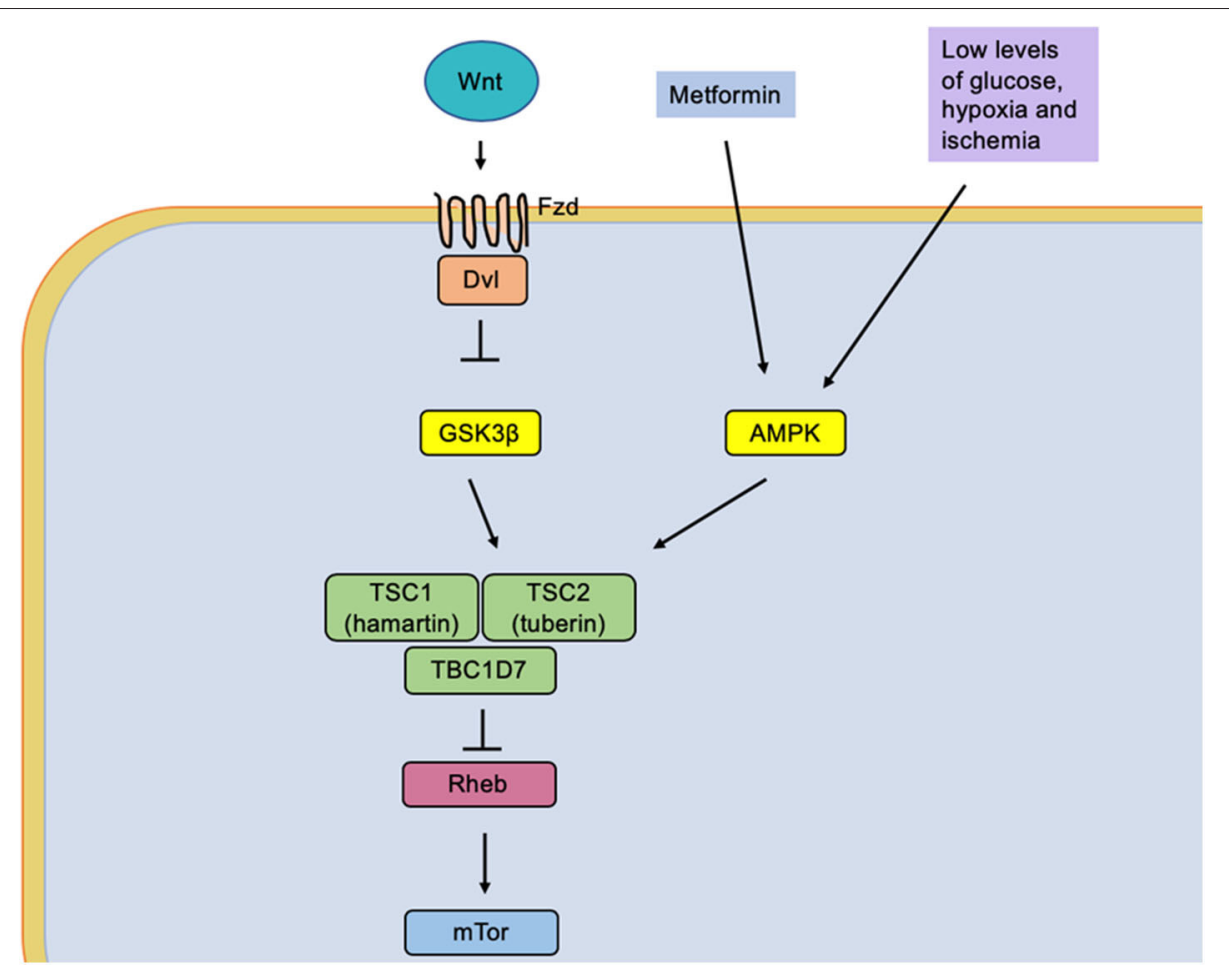

FIGURE 2 | The low glucose levels caused by caloric restriction induce an activation of the protein AMPK (adenosine monophosphate-activated by protein kinase). It simultaneously causes activation of the tuberin complex that causes an indirect inhibition of the mTOR molecular complex by the Rheb protein (homologous Ras protein-enriched brain), a direct activator of mTOR.

Wnt protein inhibits GSK3 $\beta$ through Fzd ligands, activating TSC2. When TSC2 is inhibited, it indirectly activates mTORC1 by supporting the relation between $\mathrm{mTORC} 1$ and $W n t$ pathways $(15,108)$.

This pathway responds to different extra- and intracellular cues. It also affects mitochondrial function. When mTOR is hyperactivated, it induces the production of ROS and eventually causes neuronal damage. A high level of AMPK leads to mTOR pathway regulation. AMPK is stimulated at low energy levels that later activate tuberin protein (encoded by tuberous sclerosis 2 gene, TSC2). Tuberin plus hamartin (encoded by TSC1) inhibits complex mTORC1 (113). Additionally, AMPK removes insulin and growth factors, activating protein kinase $\mathrm{B}(\mathrm{PKB} / \mathrm{Akt})$, which inhibits tuberin and activates mTORC1 (114). If there is an increase in mTOR cascade function, epilepsy also increases. Therefore, the inhibition of mTOR has shown anti-convulsive effects (115).

Diets such as the ketogenic diet and caloric restriction have shown anti-epileptic actions in several different animal models due to mTOR pathway inhibition. Among the anti-epileptic effects of CR found in epileptic inbred mice, delayed seizure onset and decreased seizure incidence are found (78), as well as increased paired-pulse inhibition, an increased threshold of maximal dentate gyrus activation, no spreading of depressionlike events (116), delayed kindling rate in seizure-prone rats (85), and a maximization after-discharge threshold in electric kindling epilepsy model (82).
There is undoubtedly a physiologic connection of the Wnt and the mTOR signaling pathways that gives us a more profound understanding of the interplay between mTORC1 and $W n t / \beta$ catenin signaling pathway. However, more research needs to be done to conclude a novel therapeutic target.

\section{KETOGENIC DIET}

Although the different mechanisms of action in diets are not fully understood yet, the KD has shown a decrease in seizures in about $50 \%$ of the patients $(50)$. About $50 \%$ of individuals treated with $\mathrm{KD}$ have reduced seizure frequency (117), even stopping seizures at all in $10-15 \%$ (118). Studies suggest that this relies on the production of ketone bodies that cause an effect on neuronal function and release of neurotransmitters, such as a decrease of glutamate and an increase of GABA synthesis.

On the other hand, it has not been set specifically which epileptic syndromes the KD could benefit, but its effectiveness has been proven in glucose transporter 1 deficiency syndrome, Angelman syndrome, and tuberous sclerosis complex, and a potential action in autoimmune epilepsy and encephalitis has been suggested due to the KD anti-inflammatory actions (119). Pyruvate dehydrogenase deficiency has been reported to have a beneficial response to the $\mathrm{KD}$. However, the $\mathrm{KD}$ is not appropriate for some patients with conditions of primary carnitine deficiencies and $\beta$-oxidation defects due to the inability 
to metabolize ketone bodies (120). A small percentage of patients have adverse effects like gastrointestinal symptoms and high serum lipids in short-term studies, which do not allow them to follow the diet as a treatment, which suggests that genetic changes are involved $(50,117)$. Currently, there are different approaches to reduce the adverse effects of the KD (121).

Moreover, 15 years ago, research found 42 genes to be involved in intracellular metabolism and signal transduction pathways, specifically oxidative phosphorylation and mitochondrial protein metabolism expressed in different ways after KD treatment (122). Additionally, a reduction in seizures was demonstrated in $50 \%$ of a group of patients with epilepsy, with the potassium sodiumactivated channel subfamily $\mathrm{T}$ after KD treatment (45).

\section{Neurotransmitters Involved in the Ketogenic Diet \\ GABA}

For epilepsy, numerous pathologic pathways produce neuronal excitability resulting in seizures, including insufficient synaptic inhibition, and changes in the receptors like low $\mathrm{GABA}_{\mathrm{A}}$ $\left(\mathrm{GABA}_{\mathrm{A}}-\mathrm{Rs}\right)$ levels in the molecular layer of the dentate gyrus shown in kindled rats (123). Ketone bodies have multiple direct and indirect effects that modify neuronal excitability, intracellular metabolic changes, and modification in cell gene expression. Furthermore, it has been confirmed that the KD and CR enhance $\mathrm{GABA}_{\mathrm{A}}$ - Rs by increasing inhibition specifically in the dentate gyrus (116), a structure highly related to epileptic activity. The inhibition of glycolysis by 2 -deoxy-D-glucose (2DG) has been observed to provide neuroprotective effects against seizures (124). Perhaps this inhibition provides a decrease in the ATP/ADP ratio. In 2013, Kossoff and Wang (125) mentioned that 2DG inhibition could prevent epileptic seizures by a different mechanism than the one presented by the KD since 2DG does not produce ketosis; however, it also increases $\mathrm{GABA}_{\mathrm{A}}$-Rs at synaptic or membrane levels due to glyceraldehyde-3-phosphate dehydrogenase (126).

\section{Aspartate; Glutamate to GABA}

It is suggested that aspartate plays a significant role in hippocampal epileptogenesis since it is synthesized by glutamate when glucose is not available and functions as the excitatory amino acid that is released after depolarization, increasing its levels in the intra-synaptic space. The $\mathrm{KD}$ increases blood branched-chain amino acids, specifically high levels of leucine in the brain, which block the transamination of glutamate to aspartate (127). Another mechanism that supports the function of the $\mathrm{KD}$ in decreasing aspartate is the reduction of oxaloacetate, which is converted to aspartate through transamination reaction (128).

Ketosis induces glutamate decarboxylase, causing fewer levels of glutamate and high levels of GABA (129), by some mechanism not yet understood. The KD response alters the glutamateglutamine cycle by intensifying the astrocytic glutamine pathway extracting glutamate from the synaptic clefts and returning it to the presynaptic neuron as a GABA precursor (Figure 3). In 2010, Juge et al. (130) showed that ketone bodies, especially acetoacetate, competed reversibly for the chlorine $\left(\mathrm{Cl}^{-}\right)$binding site in the vesicular glutamate transporter, decreasing glutamate release, which had been available to glutamic acid decarboxylase for GABA synthesis in GABAergic neurons only (131).

Another possible mechanism may be due to an inhibition of the voltage-sensitive calcium channels enhanced by GABAergic function through $\mathrm{GABA}_{\mathrm{B}}$-receptors after $\mathrm{KD}$ (132), causing greater stability among neurons in the hippocampus and control over transport proteins and $\mathrm{Na}^{+} / \mathrm{K}^{+}$-ATPase pump, causing ionic homeostasis for a more prolonged period than expected. It was demonstrated that, after KD therapy, there is a higher resistance to metabolic stress, raising the threshold to release larger amounts of ATP (10).

\section{GABA, Glutamate, and Wnt}

Wnt $5 \mathrm{a}$ in the non-canonical calcium pathway causes higher levels of $\mathrm{GABA}_{\mathrm{A}}$-Rs in the neuron surface by facilitating membrane insertion and increasing neuronal inhibition by regulating the synaptic plasticity of inhibitory circuits in the hippocampus $(31,133)$. When tyrosine-protein kinase receptor (RTK) is expressed, the non-canonical pathway of $W n t$ increases intracellular calcium ( $W n t / \mathrm{Ca}^{2+}$ pathway), causing high levels of PKC and leading to regulate channel opening and NMDAR, a receptor for glutamate. Specifically, Wnt5a maintains a basal NMDAR synaptic transmission in calcium-dependent neurons, as shown in the CA1 of the hippocampus, and it has been described that SNAP25 peptide may play a role in this mechanism as well $(107,134)$.

\section{The Ketogenic Diet Modulates the Mitochondria, so Does Wnt}

Seizures and epileptogenesis cause the mitochondria to release reactive oxygen species (ROS), causing oxidative stress and cellular macromolecule dysfunction, affecting the production of ATP and mtDNA stability. Overall, this damage increases neuronal excitability. For instance, in temporal lobe epilepsy (TLE), mitochondrial dysfunction after oxidative stress is associated with excitotoxicity and apoptosis in the hippocampus $(135,136)$. How histological and functional modifications occur in the hippocampus in TLE have been shown; some of these changes include neuronal loss in CA1 and CA3. In other types of epilepsy, gliosis and granule cell dispersion in dentate gyrus have been also demonstrated $(137,138)$.

Studies have shown that the KD decreases the reactive oxygen species of the mitochondria of the hippocampus (139), one of the most vulnerable structures to the epileptic phenomena (140). In the hippocampus, the KD up-regulates genes involved in metabolic pathways and down-regulates genes implicated in intracellular signal transduction, resulting in an increase of mitochondrial ATP synthase beta subunit and its precursor and enhancing the brain ATP production while maintaining the neuronal membranes in continued depolarization (42). Ketone bodies prevent cell death by activating the $\mathrm{K}_{\mathrm{ATP}}$ channels in the mitochondria (mitoK $\mathrm{ATP}_{\mathrm{T}}$ channel) by glycolytic reduction (141). Mitochondrial biogenesis has been proposed after a chronic ketosis state. The mitochondrial biogenesis allows an increase in the storage of phosphates, glutamate, and glutamine, resulting 


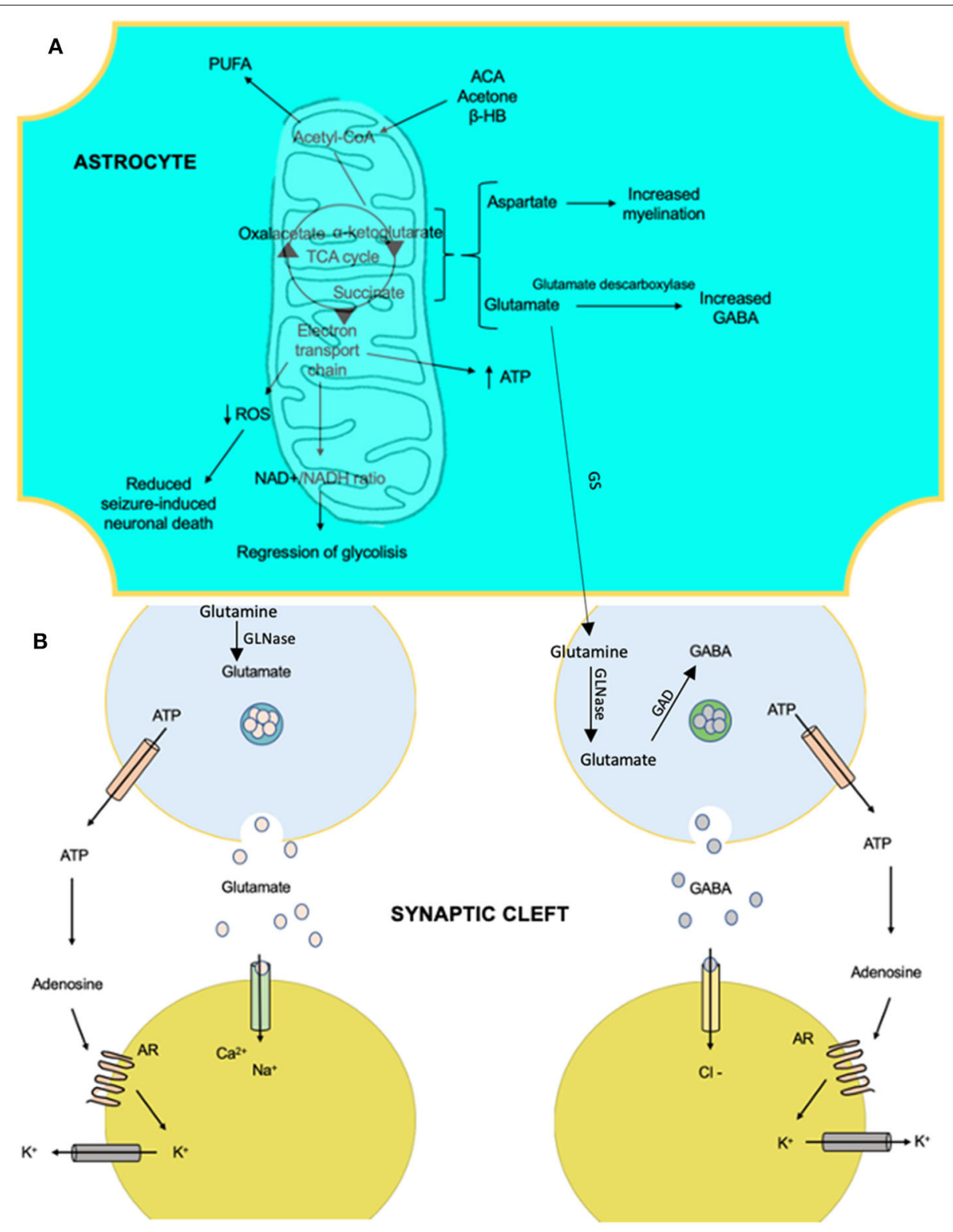

FIGURE 3 | The anti-epileptic effects that involve the metabolism of ketone bodies and the activity of neurotransmitters with the ketogenic diet. (A) Products of the mitochondria in the metabolism of ketone bodies in brain cells, which confer anti-epileptic effects. These effects are linked to changes in the amounts of neurotransmitters and influence membrane polarity. (B) The effects of certain products on ion transfer at the synapse. AR, adenosine receptor A1; ACA, acetoacetate; $\beta-\mathrm{HB}$, beta-hydroxybutyrate; GAD, glutamate decarboxylase; GS, glutamine synthetase; GLNase, glutaminase; PUFA, polyunsaturated fatty acid; ROS, reactive oxygen species.

in an ATP increase. The Wnt signals activate mitochondrial biogenesis and reactive oxygen species generation, leading to cell damage (65). The Armcx groups of proteins have a bimodal subcellular localization, associated with the mitochondrial outer membrane; its overexpression produces mitochondrial alterations, demonstrating that this family of proteins plays an important role in the regulation of mitochondrial dynamics and aggregation. These genes are expressed highly in the developing and adult nervous systems. Furthermore, higher levels of expression of Armcx3, which is part of the exclusive mammalian gene family, interacts with the Kinesin/Miro/Trak2 complex in a $\mathrm{Ca}^{2+}$-dependent manner, regulating mitochondrial dynamics and neuron trafficking. When the intracellular $\mathrm{Ca}^{2+}$ levels are depleted, there is also a degradation of Armcx3 through the Wnt signaling pathways, generating a mitochondrial aggregation effect reversed by the overexpression of Armcx 3 and evaded by the activation of PKC. Therefore, the Wnt pathway can control mitochondrial dynamics by regulating Armcx proteins (142). The canonical pathway of Wnt did not alter the pattern of Armcx3induced mitochondrial aggregation; it was also observed that the 
non-canonical pathway $W n t / \mathrm{PKC}$ regulated both mitochondrial aggregation and Armcx3 protein levels; it was reduced with the activation of the non-canonical $W n t / \mathrm{Ca}^{2+}$ pathway, suggesting that Wnt regulates mitochondrial distribution and dynamics through degradation of the Armcx3 protein (40).

Many controversies are documented about complex enzymes; there is a general agreement on the decrease of complex I, which has shown mitochondrial dysfunction. However, others differ in the alteration of complexes II, III, and IV (136). After induced seizure, complexes I and IV of the mitochondria were decreased, and an increase of complex II provoked mitochondrial dysfunction due to oxidative stress, associated to a downregulation in the encoded proteins for the electron transport chain, essential to membrane permeability, neurotransmitter biosynthesis, and the production of ATP, among other functions, resulting in a ROS increase, which continues a vicious cycle of producing oxidative stress and mitochondrial dysfunction. The KD could prevent mitochondrial complexes I, II, and III inhibition and increase uncoupling proteins (UCP2), reducing oxidative stress in the brain due to a decrease of free radicals and expressing antioxidant proteins that make the brain more resilient to oxidative stress (143).

After the $\mathrm{KD}$, an enhancement of the mitochondria increases the glutathione (GSH) levels and biosynthesis in the hippocampus, contributing to a lower level of ROS as hydrogen peroxide $\left(\mathrm{H}_{2} \mathrm{O}_{2}\right)$ and improvement of mtDNA (144). The abovementioned condition is maintained by an increase of low levels of 4-hydroxy-2 non-enal, a product of lipid peroxidation, which leads to a protective transcription factor pathway involving Nrf2 protein, increasing GSH biosynthesis by gene transcription after the KD treatment (74).

Mitochondrial permeability transition (mPT) is suggested to be the reason for cell death prevention due to the KD treatment after having been inhibited by oxidative stress. Ketone bodies act in a similar way to cyclosporine $\mathrm{A}$, which can increase the threshold of calcium-induced mPT opening (145). It also
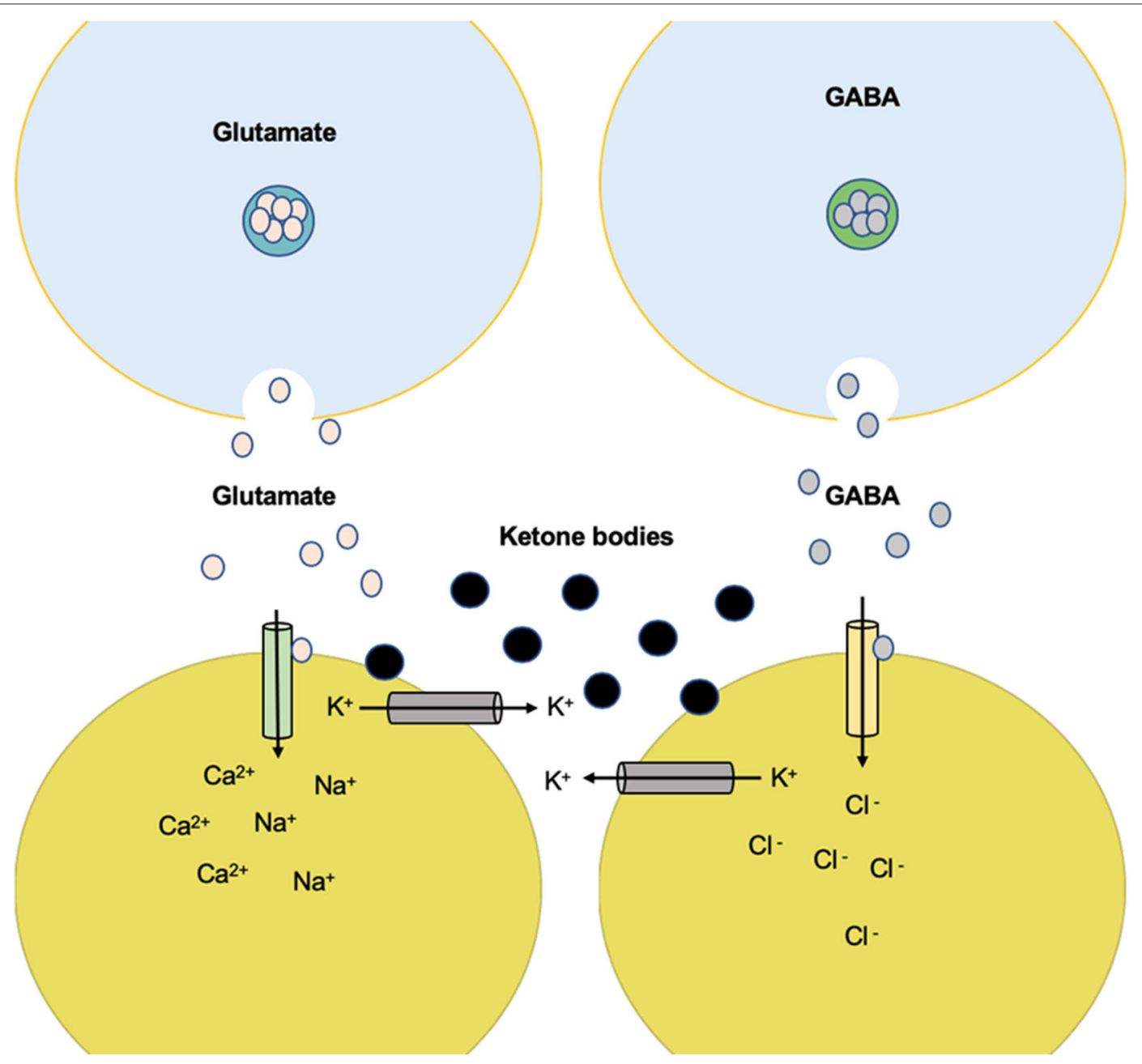

FIGURE 4 | Anticonvulsant effect of $\mathrm{K}^{+}$channel-mediated ketone body metabolism. Ketone body metabolism increases overall ATP but reduces glycolysis and glycolytic ATP synthesis. The reduction of ATP near the plasma membrane can disinhibit the KATP channels and therefore reduce electrical activity. High electrical activity (as in a seizure) increases $\mathrm{Na}^{+}$input and ATP utilization near the plasma membrane. This produces negative changes in activity through the KATP channels. The set point at which this negative feedback safety mechanism is activated is determined by the level of glycolytic ATP synthesis. 
decreases brain $\mathrm{pH}$, inhibiting proton-sensitive ion channels, while increasing monocarboxylic transporters (MCT1, a protein that transports ketone bodies to the brain) (42).

\section{Mechanisms of Action of the Ketogenic Diet and the Participation of $\mathrm{K}_{\text {ATP }}$ Channels in Neuronal Excitability}

In recent years, more and more research has been carried out on ion channels as responsible for the ketogenic effect of restrictive diets on neuronal membrane potential. The latest studies indicate that the KD modifies the $\mathrm{K}_{\mathrm{ATP}}$ channels' function. These channels are part of the metabolic state of the cell and the membrane potential due to their response and sensitivity to variations in concentrations of ATP; therefore, the channels are inhibited by high concentrations of intracellular ATP and activated by ADP (146), causing variations in the membrane potential of the neuron by allowing variations of $\mathrm{K}^{+}$ion conductance (Figure 4). In experimental models, evidence still suggests that the KD restores and increases ATP levels (147-149). We suggest that the activation of $\mathrm{K}_{\mathrm{ATP}}$ channels leads to this increase of ATP to provide its neural stability. These $\mathrm{K}_{\mathrm{ATP}}$ channels are present in multiple neural areas. Regardless of being areas with glucose-sensitive function, it presents a high expressiveness specifically in the hippocampus (150-152). $\mathrm{K}_{\mathrm{ATP}}$ channels of the neuronal membrane are inhibited in a basal state, except in states of severe metabolic deprivation (anoxia and ischemia), with both situations leading to cellular stress $(153,154)$.

A study by Shen et al. in 2016, using dopaminergic neurons of the substantia nigra, carried out a patch-clamp type registry, which showed the activation of AMPK during the "whole cell" that caused a gradual increase of the $\mathrm{K}_{\mathrm{ATP}}$ channel functionality and vice versa; the inhibition of AMPK activity caused a decrease in $\mathrm{K}_{\mathrm{ATP}}$ channels. In 2011, Ikematsu et al. (155) showed that AMPK activation generated the function of voltage-regulated $\mathrm{K}^{+}$ channels (Kv2.1) by the phosphorylation of two channel sites (s440 and s537), inducing membrane hyperpolarization. This is important because AMPK is essential for neuronal energy consumed after an epileptic seizure. Besides that, a high level of AMPK has been shown to up-regulate the $\mathrm{Bcl} 2$ modifying factor gene, preventing neuronal death in CA1 and CA3 of the hippocampus induced by seizures (61).

The participation of Bad (BCL-2 cell death agonist) in neuronal metabolism has been mentioned, proven by its genetic deletion that generates a protective effect against epileptic seizures. Bad's genetic modifications decrease glycolytic metabolism, inducing a marked increase in activity in the $\mathrm{K}_{\mathrm{ATP}}$ channels (57). Bad ablation reduces the epileptiform activity of the hippocampal-entorhinal circuit in picrotoxin-induced epileptiform neurons (partial inhibitor of $\mathrm{GABA}_{\mathrm{A}}$-Rs).
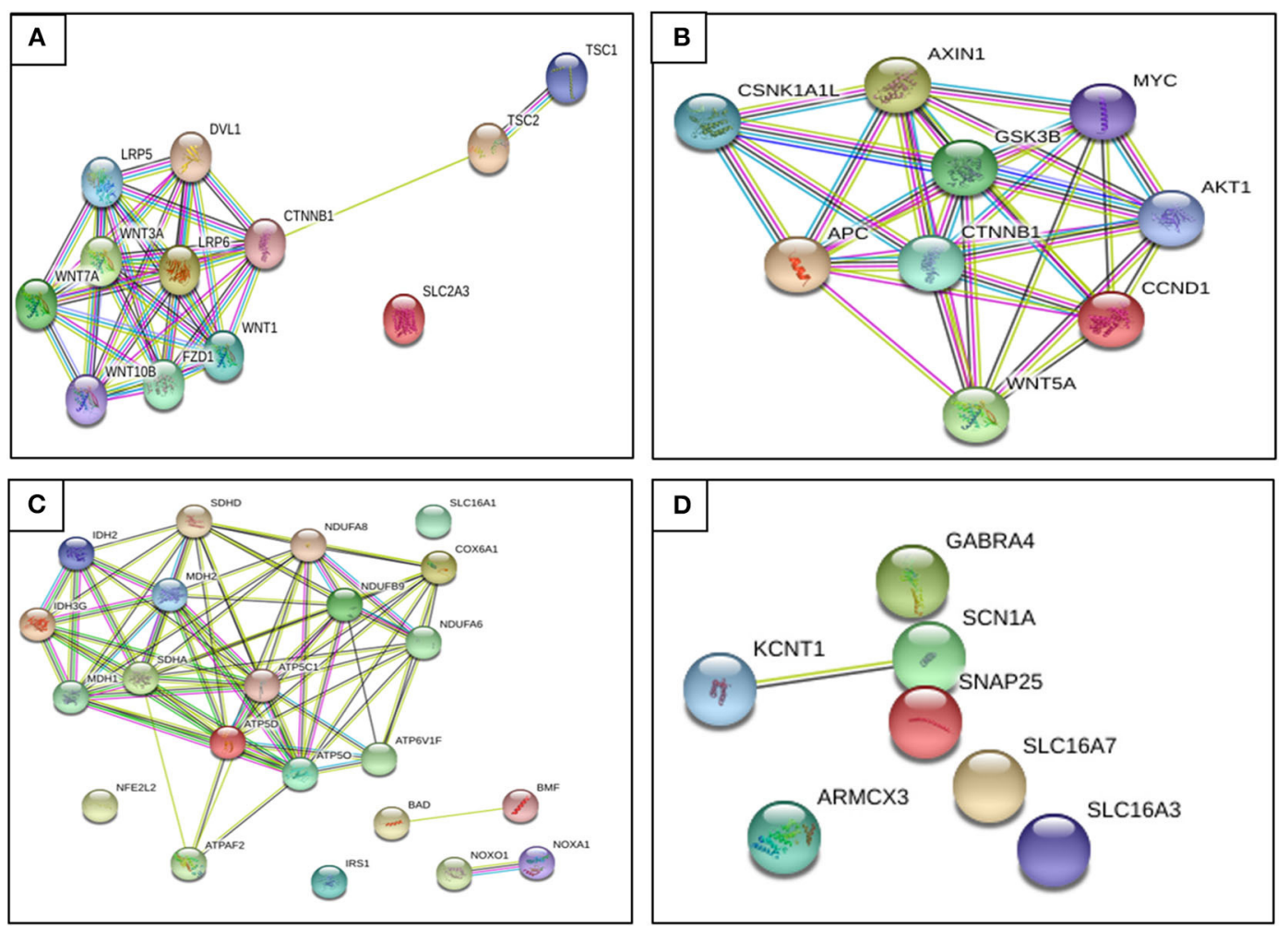

FIGURE 5 | Relationship between genes found regulated by restrictive diets in epileptogenesis. (A) Genes up-regulated on caloric restriction (CR). (B) Genes down-regulated on CR. (C) Genes up-regulated on KD. (D) Genes up-regulated on KD. We observe that almost all genes interact. Until recently, there has not been evidence described to prove some of these genes as a potential pharmacotherapy, though we hope to provide a better understanding of epileptogenesis and seizure pathophysiology and future ideas and research to find a possible diet therapy focused on gene expression (retrieved from https://string-db.org/). 
Therefore, it confers a protective effect against seizures dependent on the $\mathrm{K}_{\mathrm{ATP}}$ channels' activity (58).

Tanner et al. (156) showed that bursts of stimulation in dentate nuclei neurons increase the probability of opening the $\mathrm{K}_{\mathrm{ATP}}$ channels through the administration of the ketone body R- $\beta$-hydroxybutyrate. They also found that neuron overstimulation by triggering five action potentials by applying a current of $20 \mathrm{~Hz}$ in the same area caused a post-stimulation hyperpolarization mediated by the $\mathrm{K}_{\mathrm{ATP}}$ channels, suggesting the excitation limitation of seizure spread through the activation of KATP channels.

A study targeting substantia nigra pars reticularis (an area that participates in seizure activity) and ketone bodies observed reduction in neural excitability through $\mathrm{K}_{\mathrm{ATP}}$ channels and GABA. Ketone bodies keep $\mathrm{K}_{\mathrm{ATP}}$ channels open, which might increase the expression of the $\mathrm{GABA}_{\mathrm{B}}$ subunit (157).

An extracellular increase of $\mathrm{K}^{+}$prevents the release of $\mathrm{Ca}^{2+}$, inhibiting the signaling of the Wnt pathway and the translocation of $\beta$-catenin to the cell nucleus. Wnt ligands hyperpolarized the cells by activating $\mathrm{K}^{+}$current by $\mathrm{Ca}^{2+}$ (157). The $W n t$ response also depends on the activation of $\mathrm{Bcl} 9$ that activates genes that have response sequences to $W n t(158,159)$.

Adenosine may play a relevant mechanism of the $\mathrm{KD}$ as a neuroprotective and anticonvulsant effect. Masino et al. (160) proposed the KD as metabolic stress that would cause a decrease in the enzyme adenosine kinase, an inhibitory regulator of adenosine, inducing its increase in the cell and activating its receptors, causing a tonic inhibition of presynaptic and postsynaptic neurons through the adenosine receptor 1 (RA1) and conferring a protective effect against epileptic seizures. Moreover, adenosine has shown to increase seizures in experimental models and decrease DNA methylation, even after discontinuing the diet (161). In experimental models, the $\mathrm{KD}$ has demonstrated to improve cerebral infarcts because of its association to increase extracellular adenosine levels, reduce volume infarcts, and boost regional cerebral blood flow, again by expressing the neuroprotective effect of the KD (162).

\section{CONCLUSION}

The KD has shown a decrease in seizures through the production of ketone bodies that cause an effect on neuronal function and neurotransmitter release, such as a decrease of glutamate, enhanced mitochondrial function, an increase of GABA synthesis, and $\mathrm{K}_{\mathrm{ATP}}$ channels' activation. On the other hand, $\mathrm{CR}$ may inhibit glycolysis and, like the $\mathrm{KD}$, is involved in mitochondrial biogenesis, a decrease of oxidative stress, and inflammation reduction. The $\mathrm{KD}$ and $\mathrm{CR}$ per se downregulates and up-regulates certain genes involved in seizure activity. There is still not enough evidence, because of the limited number of studies and small sample sizes, to suggest a specific treatment related to these genes and the association with $\mathrm{K}_{\mathrm{ATP}}$ channels to control epileptic seizures. In Figure 5, we aim to show the relationship between genes found to be regulated by restrictive diets in epileptogenesis; we observed that almost all genes interact.

The molecular changes that intervene in the glycolytic metabolism of neurons are crucial in modulating the electrophysiological response to epileptic seizures. Understanding the metabolic pathways interfering with the functionality of the $\mathrm{K}_{\mathrm{ATP}}$ channels in neurons with epileptiform crises is of great importance because the evidence shows that it could be introduced as a new pharmacological target for the new therapeutic generations being formulated for the modification of these metabolic pathways. Nevertheless, there has not been current evidence described to prove that some of these genes has a potential anticonvulsant effect. We hope to provide a better understanding of epileptogenesis and seizure pathophysiology and future ideas and research to find a possible diet therapy focused on gene expression in the regulation in Wnt pathways and their regulation through the $\mathrm{K}_{\mathrm{ATP}}$ channels to reduce epileptic seizures.

\section{AUTHOR CONTRIBUTIONS}

All the authors contributed in equal ways to the writing and making of this manuscript.

\section{ACKNOWLEDGMENTS}

The present work was possible thanks to grants provided by CONACYT (287959) and the National Institute of Neurology and Neurosurgery.

\section{REFERENCES}

1. Billakota S, Devinsky O, Kim KW. Why we urgently need improved epilepsy therapies for adult patients. Neuropharmacology. (2020) 170:107855. doi: 10.1016/j.neuropharm.2019.107855

2. Kwan P, Brodie MJ. Refractory epilepsy: mechanisms and solutions. Expert Rev Neurother. (2006) 6:397-406. doi: 10.1586/14737175.6.3.397

3. Kwan P, Arzimanoglou A, Berg AT, Brodie MJ, Allen Hauser W, Mathern G, et al. Definition of drug resistant epilepsy: consensus proposal by the adhoc Task Force of the ILAE Commission on Therapeutic Strategies. Epilepsia. (2009) 51:1069-77. doi: 10.1111/j.1528-1167.2009.02397.x

4. Rubio C, Custodio V, Juárez F, Paz C. Stimulation of the superior cerebellar peduncle during the development of amygdaloid kindling in rats. Brain Res. (2004) 1010:151-5. doi: 10.1016/j.brainres.2004.03.015

5. Seymour KJ, Bluml S, Sutherling J, Sutherling W, Ross BD Identification of cerebral acetone by 1H-MRS in patients with epilepsy controlled by ketogenic diet. MAGMA. (1999) 8:33-42. doi: 10.1016/S1352-8661(99)00006-X

6. Vannucci RC, Yager JY, Vannucci SJ. Cerebral glucose and energy utilization during the evolution of hypoxic- ischemic brain damage in the immature rat. J Cereb Blood Flow Metab. (1994) 14:279-88. doi: 10.1038/jcbfm.1994.35

7. Wilder RM. The effects of ketonemia on the course of epilepsy. Mayo Clin Proc. (1921) 2:307-8.

8. Wang HS, Lin KL. Ketogenic diet: an early option for epilepsy treatment, instead of a last choice only. Biomed J. (2013) 36:167. doi: 10.4103/2319-4170.107155

9. Talevi A, Rocha L. Antiepileptic Drug Discovery. 1st edn. New York, NY: Springer Science; Business Media (2016). p. 163-74. 
10. Bough KJ, Wetherington J, Hassel B, Pare JF, Gawryluk JW, Greene JG, et al. Mitochondrial biogenesis in the anticonvulsant mechanism of the ketogenic diet. Ann Neurol. (2006) 60:223-35. doi: 10.1002/ana.20899

11. Cisternas P, Salazar P, Silva-Álvarez C, Barros LF, Inestrosa NC. Activation of Wnt signaling in cortical neurons enhances glucose utilization through glycolysis. J Biol Chem. (2016) 291:25950-64. doi: 10.1074/jbc.M116.735373

12. Ma W, Berg J, Yellen G. Ketogenic diet metabolites reduce firing in central neurons by opening KATP channels. J Neurosci. (2007) 27:361825. doi: 10.1523/JNEUROSCI.0132-07.2007

13. Manning BD, Toker A. AKT/PK signaling: navigating the network. Cell. (2017) 169:381-405. doi: 10.1016/j.cell.2017.04.001

14. Kuhn I, Bartholdi MF, Salamon H, Feldman RI, Roth RA, Johnson PH. Identification of AKT-regulated genes in inducible MERAkt cells. Physiol Genomics. (2001) 7:105-14. doi: 10.1152/physiolgenomics.00052.2001

15. Inoki $\mathrm{K}$, Ouyang $\mathrm{H}$, Zhu T, Lindvall $\mathrm{C}$, Wang $\mathrm{Y}$, Zhang X, et al. TSC2 integrates Wnt and energy signals via a coordinated phosphorylation by AMPK and GSK3 to regulate cell growth. Cell. (2006) 126:95568. doi: 10.1016/j.cell.2006.06.055

16. Groden J, Thliveris A, Samowitz W, Carlson M, Gelbert L, Albertsen H, et al. Identification and characterization of the familial adenomatous polyposis coli gene. Cell. (1991) 66:589-600. doi: 10.1016/0092-8674(81)90021-0

17. Kinzler KW, Nilbert MC, Su LK, Vogelstein B, Bryan TM, Levy DB, et al. Identification of FAP locus genes from chromosome 5q21. Science. (1991) 253:661-5. doi: 10.1126/science.1651562

18. Tamai K, Zeng X, Liu C, Zhang X, Harada Y, Chang Z, et al. A mechanism for Wnt coreceptor activation. Mol Cell. (2004) 13:14956. doi: 10.1016/S1097-2765(03)00484-2

19. Nusse R. Cell biology: relays at the membrane. Nature. (2005) 438:7479.doi: 10.1038/438747a

20. Ikeda S, Kishida S, Yamamoto H, Murai H, Koyama S, Kikuchi A. Axin, a negative regulator of the Wnt signaling pathway, forms a complex with GSK-3beta and beta-catenin and promotes GSK-3betadependent phosphorylation of beta-catenin. Embo J. (1998) 17:137184. doi: 10.1093/emboj/17.5.1371

21. Behrens J, Jerchow BA, Wurtele M, Grimm J, Asbrand C, Wirtz R, et al. Functional interaction of an axin homolog, conductin, with $\beta$-catenin, APC, and GSK3ß. Science. (1988) 280:596-9. doi: 10.1126/science.280. 5363.596

22. Rubio C, Taddei E, Acosta J, Custodio V, Paz C. Neuronal excitability in epileptogenic zones regulated by the Wnt/B-Catenin pathway. CNS Neurol Disord. (2020) 19:2-11. doi: 10.2174/1871527319666200120143133

23. Desjardins PR, Lue, PF, Liew CC, Gornal AG. Purification and properties of rat liver nuclear protein kinases. Can. J. Biochem. (1972) 50:1249-59. doi: $10.1139 / 072-170$

24. Ozawa M, Baribault H, Kemler R. The cytoplasmic domain of the cell adhesion molecule uvomorulin associates with three independent proteins structurally related in different species. EMBO J. (1989) 8:17117. doi: 10.1002/j.1460-2075.1989.tb03563.x

25. Hodges SL, Lugo JN. Wnt/ $\beta$-catenin signaling as a potential target for novel epilepsy therapies. Epilepsy Res. (2018) 146:916. doi: 10.1016/j.eplepsyres.2018.07.002

26. Xiong Y, Connolly T, Futcher B, Beach D, Human. D-type cyclin. Cell Press. (1991) 65:691-9. doi: 10.1016/0092-8674(91)90100-D

27. Siegfried E, Chou TB, Perrimon N. Wingless signaling acts through zeste-white 3, the Drosophila homolog of glycogen synthase kinase3 , to regulate engrailed and establish cell fate. Cell. (1992) 71:116779. doi: 10.1016/S0092-8674(05)80065-0

28. Bishop JM, Varmus H. Functions and origins of retroviral transforming genes. In: Weis R, Teich N, Varmus H, Coffin JM, editors. RNA Tumor Viruses. Cold Spring Harbor: Cold Spring Harbor Laboratory. (1985). p. 249356.

29. Zhou J, Wu M, Taniyasu S, Besso H, Tanaka O, Saruwatari Y, et al. Dammarane- saponins of sanchi-ginseng, roots of panax notoginseng. Structures of new saponins, notoginsenosides-R1 and -R2, and identification of ginsenosides-Rg2 And -Rh1. Chem Pharm Bull. (1981) 29:284450. doi: $10.1248 / \mathrm{cpb} .29 .2844$

30. Adamson M, Dennis C, Delaney S, Christiansen J, Monkley S, Kozak C, et al. Isolation and genetic mapping of two novel members of the murine Wnt gene family, Wnt11 and Wnt12, and the mapping of Wnt5a and Wnt7a. Genomics. (1994) 24:9-13. doi: 10.1006/geno.1994.1575

31. Cuitino L, Godoy JA, Farías GG, Couve A, Bonansco C, Fuenzalida $\mathrm{M}$, et al. Wnt-5a modulates recycling of functional GABAA receptors on hippocampal neurons. J Neurosci. (2010) 30:8411-20. doi: 10.1523/JNEUROSCI.5736-09.2010

32. Peifer M, Rauskolb C, Williams M, Riggleman B, Wieschaus E. The segment polarity gene armadillo interacts with the wingless signaling pathway in both embryonic and adult pattern formation. Development. (1991) 111:1029-43.

33. Perrimon N, Mahowald AP. Multiple functions of segment polarity genes in Drosophila. Dev Biol. (1987) 119:587600. doi: 10.1016/0012-1606(87)90061-3

34. Wehrli M, Dougan ST, Caldwell K, O'Keefe L, Schwartz S, Vaizel- Ohayon D, et al. Arrow encodes an LDL-receptor-related protein essential for Wingless signalling. Nature. (2000) 407:527-30. doi: 10.1038/35035110

35. Kayano T, Fukumoto H, Eddy RL, et al. Evidence for a family of human glucose transporter-like proteins. Sequence and gene localization of a protein expressed in fetal skeletal muscle and other tissues. J Biol Chem. (1988) 263:15245-8.

36. Janssen L, Sandkuyl L, Merkens E, Maat-Kievit J, Sampson J, Fleury P, et al. Genetic heterogeneity in tuberous sclerosis. Genomics. (1990) 8:23742. doi: 10.1016/0888-7543(90)90277-2

37. Nusse R, Varmus HE. Wnt genes. Cell. (1992) 69:107387. doi: 10.1016/0092-8674(92)90630-U

38. Lee F, Lane T, Kuo A, Shackleford G, Leder P. Insertional mutagenesis identifies a member of the wnt gene family as a candidate oncogene in the mammary epithelium of Int-2/Fgf-3 transgenic mice. Proc Natl Acad Sci USA. (1995) 92:2268-72. doi: 10.1073/pnas.92.6.2268

39. Roelink H, Wagenaar E, Lopes da Silva S, Nusse R. Wnt-3, a gene activated by proviral insertion in mouse mammary tumors, is homologous to Int-1/Wnt1 and is normally expressed in mouse embryos and adult brain. Proc Natl Acad Sci USA. (1990) 87:4519-23. doi: 10.1073/pnas.87.12.4519

40. Serrat R, López-Doménech G, Mirra S, Quevedo M, GarciaFernàndez J, Ulloa $\mathrm{F}$, et al. (2013). The non-canonical Wnt/PKC pathway regulates mitochondrial dynamics through degradation of the arm-like domain-containing protein Alex3. PLoS ONE. (2013) 8:e67773. doi: 10.1371/journal.pone.0067773

41. Kurochkin I, Yonemitsu N, Funahashi S, Nomura H. ALEX1, a novel human armadillo repeat protein that is expressed differentially in normal tissues and carcinomas. Biochem Biophys Res Commun. (2000) 280:3407. doi: 10.1006/bbrc. 2000.4125

42. Sook Noh H, Po Lee H, Wook Kim D, Soo Kang S, Jae Cho G, Rho $\mathrm{JM}$, et al. A cDNA microarray analysis of gene expression profiles in rat hippocampus following a ketogenic diet. Mol Brain Res. (2004) 129:807. doi: 10.1016/j.molbrainres.2004.06.020

43. Khrestchatisky M, MacLennan A, Chiang M, Xu W, Jackson M, Brecha N, et al. A novel $\alpha$ subunit in rat brain GABAA receptors. Neuron. (1989) 3:745-53. doi: 10.1016/0896-6273(89)90243-2

44. Paulais M, Lachheb S, Teulon J. A Na+- and Cl-activated $\mathrm{K}+$ channel in the thick ascending limb of mouse kidney. J Gen Physiol. (2006) 127:20515. doi: 10.1085/jgp.200509360

45. Borlot F, Abushama A, Morrison-Levy N, Jain P, Puthenveettil VK, Abukhalid $\mathrm{M}$, et al. KCNT1-related epilepsy: an international multicenter cohort of 27 pediatric cases. Epilepsia. (2020) 61:679-92. doi: 10.1111/epi.16480

46. Garcia C, Brown M, Pathak R, Goldstein J. cDNA Cloning of MCT2, a second monocarboxylate transporter expressed in different cells than MCT1. J Biol Chem. (1995) 270:1843-9. doi: 10.1074/jbc.270.4.1843

47. Cho CH. Commentary: targeting LDH enzymes with a stiripentol analog to treat epilepsy. Front Cell Neurosci. (2015) 9:264. doi: 10.3389/fncel.2015.00264

48. Price NT, Jackson VN, Halestrap AP. Cloning and sequencing of four new mammalian monocarboxylate transporter (MCT) homologues confirms the existence of a transporter family with an ancient past. Biochem J. (1998) 329:321-28. doi: 10.1042/bj3290321

49. Noda M, Ikeda T, Kayano T, Suzuki H, Takeshima H, Kurasaki M, et al. Existence of distinct sodium channel messenger rnas in rat brain. Nature. (1986) 320:188-92. doi: 10.1038/320188a0 
50. Dutton SBB, Escayg A. Genetic influences on ketogenic diet efficacy. Epilepsia. (2008) 49:67-9. doi: 10.1111/j.1528-1167.2008.01839.x

51. Oyler G, Higgins G, Hart R, Battenberg E, Billingsley M, Bloom F, et al. The identification of a novel synaptosomal-associated protein, SNAP-25, differentially expressed by neuronal subpopulations. J Cel Biol. (1989) 109:3039-52. doi: 10.1083/jcb.109.6.3039

52. Nonneman D, Rohrer G. Comparative mapping of a region on chromosome 10 containing qtl for reproduction in swine. Animal Genetics. (2002) 34:426. doi: 10.1046/j.1365-2052.2003.00928.x

53. Jordan MEAM, Breen G. Molecular cloning of an import precursor of the -subunit of the human mitochondrial ATP synthase complex. Biochim Biophys Acta. (1992) 1130:123-6. doi: 10.1016/0167-4781(92)90477-H

54. Devenish R, Prescott M, Boyle G, Nagley P. The oligomycin axis of mitochondrial ATP synthase: OSCP and the proton channel. J Bioenerg Biomembranes. (2000) 32:507-15. doi: 10.1023/A:1005621125812

55. Yokoyama K, Ohkuma S, Taguchi H, Yasunaga T, Wakabayashi T, Yoshida M. V-type H+ - ATPase/Synthase from a termophillic eubacterium, thermus thermophilus. J Biol Chem. (2000) 275:13955-61. doi: 10.1074/jbc.275.18.13955

56. Wang Z, White P, Ackerman S. Atp11p And Atp12p are assembly factors for the F1-Atpase in human mitochondria. J Biol Chem. (2001) 276:307738. doi: 10.1074/jbc.M104133200

57. Giménez-Cassina A, Martínez-François JR, Fisher JK, Szlyk B, Polak K, Wiwczar J, et al. BAD-Dependent regulation of fuel metabolism and KATP channel activity confers resistance to epileptic seizures. Neuron. (2012) 74:719-30. doi: 10.1016/j.neuron.2012.03.032

58. MartÍnez-François JR, Fernández-Agüera MC, Nathwani N, Lahmann C, Burnham VL, Danial NN, et al. BAD and KATP channels regulate neuron excitability and epileptiform activity. Elife. (2018) 7:e32721. doi: 10.7554/eLife.32721

59. Yang E, Zha J, Jockel J, Boise L, Thompson C, Korsmeyer S. Bad, a heterodimeric partner for $\mathrm{Bcl}-\mathrm{Xl}$ and $\mathrm{Bcl}-2$, displaces Bax and promotes cell death. Cell Press. (1995) 80:285-91. doi: 10.1016/0092-8674(95)90411-5

60. Puthalakath H, Villunger A, O'Reilly L, Beaumont J, Coultas L, Cheney R, et al. Bmf: A proapoptotic $\mathrm{BH} 3$-only protein regulated by interaction with the myosin V actin motor complex, activated by anoikis. Science. (2001) 293:1829-32. doi: 10.1126/science.1062257

61. Yang Y, Zhu B, Zheng F, Li Y, Zhang Y, Hu Y, et al. Chronic metformin treatment facilitates seizure termination. Biochem Biophys Res Commun. (2017) 484:450-5. doi: 10.1016/j.bbrc.2017.01.157

62. Smith EO, Lomax MI. Structural organization of the bovine gene for the heart/muscle isoform of cytochrome c oxidase subunit via. Biochim Biophys Acta. (1993) 1174:63-71. doi: 10.1016/0167-4781(93)90092-R

63. Shiga K. lsoenzyme Pattern of NADP Dependent Isocitrate Dehydrogenase in Human Tissue and the Effect of Manganese and Magnesium on Tetrazolium Method. Japanese J Clin Chem. (1978) 7:63-71. doi: 10.14921/jscc1971b.6.1_63

64. Okamoto K, Matsuzaka Y, Yoshikawa Y, Takaki A, Kulski J, Tamiya G, et al. Identification of nad+-dependent isocitrate dehydrogenase $3 \gamma$-like (IDH3GL) gene and its genetic polymorphisms. GENE. (2003) 323:1418. doi: 10.1016/j.gene.2003.09.014

65. Yoon JC, Ng A, Kim BH, Bianco A, Xavier RJ, Elledge SJ. Wnt signaling regulates mitochondrial physiology and insulin sensitivity. Genes Dev. (2010) 24:1507-18. doi: 10.1101/gad.1924910

66. Sun X, Miralpeix M, Myers M, Glasheen E, Backer J, Kahn C, et al. Expression and function of IRS-1 in insulin signal transmission. J Biol Chem. (1992) 267:22662-22612.

67. Mowbray J. Evidence for the role of a specific monocarboxylate transporter in the control of pyruvate oxidation by rat liver mitochondria. North Holland Publishing Company. (1974) 44:344-7. doi: 10.1016/0014-5793(74)81174-9

68. Conde-del Pino E, Pérez-Vilar M, Cintrón-Rivera A, Señeriz R. Studies in schistosoma mansoni. I. malic and lactic dehydrogenase of adult worms and cercariae. Exp Parasitol. (1966) 18:3206. doi: 10.1016/0014-4894(66)90033-6

69. Dunbar D, Shibasaki Y, Dobbie L, Andersson B, Brookes B. In situ hybridization mapping of genomic clones for five human respiratory chain complex I genes. Cytogenet Cell Genet. (1997) 78:21-4. doi: 10.1159/000134618
70. Triepels R, van den Heuvel L, Loeffen J, Smeets R, Trijbels F, Smeitink J. The nuclear-encoded human NADH:ubiquinone oxidoreductase NDUFA8 subunit: cdna cloning, chromosomal localization, tissue distribution, and mutation detection in complex-I-deficient patients. Human Genetics. (1998) 103:557-63. doi: 10.1007/s004390050869

71. Walker JE, Arizmendi JM, Dupuis A, et al. Sequences of 20 subunits of NADH:ubiquinone oxidoreductase from bovine heart mitochondria. Application of a novel strategy for sequencing proteins using the polymerase chain reaction. J Mol Biol. (1992) 226:1051-72. doi: 10.1016/0022-2836(92)91052-Q

72. Bánfi B, Clark R, Steger K, Krause K. Two novel proteins activate superoxide generation by the NADPH oxidase NOX1. J Biol Chem. (2002) 278:35103. doi: 10.1074/jbc.C200613200

73. Scheck AC, Abdelwahab MG, Fenton KE, Stafford P. The ketogenic diet for the treatment of glioma: insights from genetic profiling. Epilepsy Res. (2012) 100:327-37. doi: 10.1016/j.eplepsyres.2011.09.022

74. Milder J, Patel M. Modulation of oxidative stress and mitochondrial function by the ketogenic diet. Epilepsy Res. (2012) 100:295303. doi: 10.1016/j.eplepsyres.2011.09.021

75. Moi P, Chan K, Asunis I, Cao A, Kan Y. Isolation of NF-E2-Related Factor 2 (Nrf2), a NF-E2-like basic leucine zipper transcriptional activator that binds to the tandem NF-E2/AP1 repeat of the beta-globin locus control region. Genetics. (1994) 91:9926-30. doi: 10.1073/pnas.91.21.9926

76. Wood D, Darlison M, Wilde R, Guest J. Nucleotide sequence encoding the flavoprotein and hydrophobic subunits of the succinate dehydrogenase of Escherichia Coli. Biochem J. (1984) 222:519-34. doi: 10.1042/bj2220519

77. Weindruch R, Walford RL, Fligiel S, Guthrie D. The retardation of aging in mice by dietary restriction: longevity, cancer, immunity and lifetime energy intake. J Nutr. (1986) 116:641-54. doi: 10.1093/jn/116.4.641

78. Greene AE, Todorova MT, McGowan R, Seyfried TN. Caloric restriction inhibits seizure susceptibility in epileptic EL mice by reducing blood glucose. Epilepsia. (2001) 42:1371-8. doi: 10.1046/j.1528-1157.2001.17601.x

79. Duan W, Guo Z, Jiang H, Ware M, Li XJ, Mattson MP. Dietary restriction normalizes glucose metabolism and BDNF levels, slows disease progression, and increases survival in huntingtin mutant mice. Proc Natl Acad Sci USA. (2003) 100:2911-6. doi: 10.1073/pnas.0536856100

80. Stafstrom C, Rho J. Epilepsy And The Ketogenic Diet. 1st edn. Totowa, NJ: Humana Press (2010). p. 247-64.

81. Bough KJ, Valiyil R, Han FT, Eagles DA. Seizure resistance is dependent upon age and calorie restriction in rats fed a ketogenic diet. Epilepsy Res. (1999) 35:21-8. doi: 10.1016/S0920-1211(98)00125-9

82. Phillips-Farfán BV, Rubio MC, Custodio V, Paz C, Carvajal KG. Caloric restriction protects against electrical kindling of the amygdala by inhibiting the mTOR signaling pathway. Front Cell Neurosci. (2015) 9:90. doi: 10.3389/fncel.2015.00090

83. Thio LL, Erbayat-Altay E, Rensing N, Yamada KA. Leptin contributes to slower weight gain in juvenile rodents on a ketogenic diet. Pediatr Res. (2006) 60:413-7. doi: 10.1203/01.pdr.0000238244.54610.27

84. Plank M, Wuttke D, Van Dam S, Clarke SA, De Magalhães JP. A meta-analysis of caloric restriction gene expression profiles to infer common signatures and regulatory mechanisms. Mol Biosyst. (2012) 8:133949. doi: $10.1039 / \mathrm{c} 2 \mathrm{mb} 05255 \mathrm{e}$

85. Azarbar A, McIntyre DC, Gilby KL. Caloric restriction alters seizure disposition and behavioral profiles in seizure-prone (fast) versus seizure-resistant (slow) rats. Behav Neurosci. (2010) 124:106-14. doi: 10.1037/a0018307

86. Goddard GV, McIntyre DC, Leech CK. A permanent change in brain function resulting from daily electrical stimulation. Exp Neurol. (1969) 25:295-330. doi: 10.1016/0014-4886(69)90128-9

87. Kawamura MJr, Ruskin DN, Masino SA. Metabolic autocrine regulation of neurons involves cooperation among pannexin hemichannels, adenosine receptors, and KATP channels. J Neurosci. (2010) 30:3886-95. doi: 10.1523/JNEUROSCI.0055-10.2010

88. Contestabile A, Ciani E, Contestabile A. Dietary restriction differentially protects from neurodegeneration in animal models of excitotoxicity. Brain Res. (2004) 1002:162-6. doi: 10.1016/j.brainres.2004.01.005

89. Benzler J, Ganjam GK, Krüger M, Pinkenburg O, Kutschke M, Stöhr S, et al. Hypothalamic glycogen synthase kinase $3 \beta$ has a central role in 
the regulation of food intake and glucose metabolism. Biochem J. (2012) 447:175-84. doi: 10.1042/BJ20120834

90. Benzler J, Andrews ZB, Pracht C, Stöhr S, Shepherd PR, Grattan DR, et al. Hypothalamic Wnt signalling is impaired during obesity and reinstated by leptin treatment in male mice. Endocrinology. (2013) 154:473745. doi: 10.1210/en.2013-1746

91. Attwell D, Laughlin SB. An energy budget for signaling in the grey matter of the brain. J Cereb Blood Flow Metab. (2001) 21:113345. doi: 10.1097/00004647-200110000-00001

92. Howarth C, Gleeson P, Attwell D. Updated energy budgets for neural computation in the neocortex and cerebellum. J Cereb Blood Flow Metab. (2012) 32:1222-32. doi: 10.1038/jcbfm.2012.35

93. Manning BD, Tee AR, Logsdon MN, Blenis J, Cantley LC. Identification of the tuberous sclerosis complex-2 tumor suppressor gene product tuberin as a target of the phosphoinositide 3-kinase/Akt pathway. Mol Cell. (2002) 10:151-62. doi: 10.1016/S1097-2765(02)00568-3

94. Patel P, Woodgett JR. Glycogen Synthase Kinase 3: A Kinase for All Pathways?. Curr Top Dev Biol. (2017) 123:277-302. doi: 10.1016/bs.ctdb.2016.11.011

95. Chafey P, Finzi L, Boisgard R, Caüzac M, Clary G, Broussard C, et al. Proteomic analysis of $\beta$-catenin activation in mouse liver by DIGE analysis identifies glucose metabolism as a new target of the Wnt pathway. Proteomics. (2009) 9:3889-900. doi: 10.1002/pmic.200800609

96. Budnik V, Salinas PC. Wnt signaling during synaptic development and plasticity. Curr Opin Neurobiol. (2011) 21:151-9. doi: 10.1016/j.conb.2010.12.002

97. Inestrosa NC, Varela-Nallar L. Wnt signaling in the nervous system and in Alzheimer's disease. J Mol Cell Biol. (2014) 6:64-74. doi: $10.1093 / \mathrm{jmcb} / \mathrm{mjt} 051$

98. Grumolato L, Liu G, Mong P, Mudbhary R, Biswas R, Arroyave R, et al. Canonical and non-canonical Wnts use a common mechanism to activate completely unrelated coreceptors. Genes Dev. (2010) 24:251730. doi: 10.1101/gad.1957710

99. Chien AJ, Conrad WH, Moon RT. A Wnt survival guide: from flies to human disease. J Invest Dermatol. (2009) 129:1614-27. doi: 10.1038/jid.2008.445

100. Koeller HB, Ross ME, Glickstein SB. Cyclin D1 in excitatory neurons of the adult brain enhances kainate-induced neurotoxicity. Neurobiol Dis. (2008) 31:230-41. doi: 10.1016/j.nbd.2008.04.010

101. Quesada I, Rovira JM, Martin F, Roche E, Nadal A, Soria B. Nuclear KATP channels trigger nuclear $\mathrm{Ca}(2+)$ transients that modulate nuclear function. Proc Natl Acad Sci USA. (2002) 99:9544-9. doi: 10.1073/pnas.142039299

102. Jeon WJ, Kim SH, Seo MS, Kim Y, Kang UG, Juhnn YS, et al. Repeated electroconvulsive seizure induces c-Myc down-regulation and Bad inactivation in the rat frontal cortex. Exp Mol Med. (2008) 40:43544. doi: $10.3858 / \mathrm{emm} .2008 .40 .4 .435$

103. Rubio C, Rosiles-Abonce A, Trejo-Solís C, Rubio-Osornio M, Mendoza C, Custodio $\mathrm{V}$, et al. Increase signaling of $\mathrm{Wnt} / \beta$-catenin pathway and presence of apoptosis in cerebellum of kindled rats. CNS Neurol Disord. (2017) 16:772-80. doi: 10.2174/1871527316666170117114513

104. Rima M, Daghsni M, Lopez A, Fajloun Z, Lefrancois L, Dunach M, et al. Down- regulation of the Wnt/ $\beta$-catenin signaling pathway by Cacnb4. Mol Biol Cell. (2017) 28:3699-708. doi: 10.1091/mbc.e17-01-0076

105. Logan CY, Nusse R. The Wnt signaling pathway in development and disease. Annu Rev Cell Dev Biol. (2004) 20:781810. doi: 10.1146/annurev.cellbio.20.010403.113126

106. Kilian B, Mansukoski H, Barbosa FC, Ulrich F, Tada M, Heisenberg $\mathrm{CP}$. The role of Ppt/Wnt5 in regulating cell shape and movement during zebrafish gastrulation. Mech Dev. (2003) 120:467-76. doi: 10.1016/s0925-4773(03)00004-2

107. McQuate A, Latorre-Esteves E, Barria A. A Wnt/calcium signaling cascade regulates neuronal excitability and trafficking of NMDARs. Cell Rep. (2017) 21:60-9. doi: 10.1016/j.celrep.2017.09.023

108. Inoki $\mathrm{K}, \mathrm{Li} \mathrm{Y}, \mathrm{Zhu} \mathrm{T}, \mathrm{Wu} \mathrm{J}$, Guan KL. TSC2 is phosphorylated and inhibited by Akt and suppresses mTOR signalling. Nat Cell Biol. (2002) 4:648-57. doi: 10.1038/ncb839

109. Liu J, Reeves C, Michalak Z. Evidence for mTOR pathway activation in a spectrum of epilepsy-associated pathologies. Acta Neuropathol Commun. (2014) 2:71. doi: 10.1186/2051-5960-2-71
110. Loewith R, Jacinto E, Wullschleger S, Lorberg A, Crespo JL, Bonenfant $\mathrm{D}$, et al. Two TOR complexes, only one of which is rapamycin sensitive, have distinct roles in cell growth control. Mol Cell. (2002) 10:45768. doi: 10.1016/S1097-2765(02)00636-6

111. Galanopoulou AS, Gorter JA, Cepeda C. Finding a better drug for epilepsy: the mTOR pathway as an antiepileptogenic target. Epilepsia. (2012) 53:111930. doi: 10.1111/j.1528-1167.2012.03506.x

112. Zeng $\mathrm{H}, \mathrm{Lu} \mathrm{B}, \mathrm{Zamponi} \mathrm{R}$, et al. mTORC1 signaling suppresses Wnt/ $\beta$-catenin signaling through DVL-dependent regulation of Wnt receptor FZD level. Proc Natl Acad Sci USA. (2018) 115:E103629. doi: 10.1073/pnas.1808575115

113. Potter WB, O'Riordan KJ, Barnett D, Osting SMK, Wagoner M, Burger C, et al. Metabolic regulation of neuronal plasticity by the energy sensor AMPK. PLoS ONE. (2010) 5:e8996. doi: 10.1371/journal.pone.0008996

114. Wong M. Mammalian target of rapamycin (mTOR) pathways in neurological diseases. Biomed J. (2013) 36:40-50. doi: 10.4103/2319-4170.110365

115. Crino PB. The mTOR signalling cascade: paving new roads to cure neurological disease. Nat Rev Neurol. (2016) 12:379-92. doi: 10.1038/nrneurol.2016.81

116. Bough KJ, Schwartzkroin PA, Rho JM. Calorie restriction and ketogenic diet diminish neuronal excitability in rat dentate gyrus in vivo. Epilepsia. (2003) 44:752-60. doi: 10.1046/j.1528-1157.2003.55502.x

117. Martin-McGill KJ, Jackson CF, Bresnahan R, Levy RG, Cooper PN. Ketogenic diets for drug-resistant epilepsy. Cochrane Database Syst Rev. (2018) 11:CD001903. doi: 10.1002/14651858.CD001903.pub4

118. Freeman JM, Kossoff EH, Hartman AL. The ketogenic diet: one decade later. Pediatrics. (2007) 119:535-43. doi: 10.1542/peds.2006-2447

119. Husari KS, Cervenka MC. The ketogenic diet all grown up-Ketogenic diet therapies for adults. Epilepsy Res. (2020) 162:106319. doi: 10.1016/j.eplepsyres.2020.106319

120. Schoeler NE, Simpson Z, Whiteley VJ, Nguyen P, Meskell R, Lightfoot $\mathrm{K}$, et al. Biochemical assessment of patients following ketogenic diets for epilepsy: Current practice in the UK and Ireland. Epilepsia Open. (2020) 5:73-9. doi: 10.1002/epi4.12371

121. Blackford R. Not your parents' ketogenic diet and flexibility in 2020. Epilepsy Res. (2020) 162:106307. doi: 10.1016/j.eplepsyres.2020.106307

122. Stafford P, Abdelwahab MG, Kim DY, Preul MC, Rho JM, Scheck AC. The ketogenic diet reverses gene expression patterns and reduces reactive oxygen species levels when used as an adjuvant therapy for glioma. Nutr Metab. (2010) 7:74. doi: 10.1186/1743-7075-7-74

123. O’Donnell-Luria AH, Pais LS, Faundes V, Wood JC, Sveden A, Luria V, et al. Heterozygous variants in kmt2e cause a spectrum of neurodevelopmental disorders and epilepsy. Am J Hum Genet. (2019) 104:1210-22. doi: 10.1016/j.ajhg.2019.03.021

124. Garriga-Canut M, Schoenike B, Qaz R, Bergendahl K, Daley TJ, Pfender $\mathrm{RM}$, et al. 2-Deoxy-D-glucose reduces epilepsy progression by NRSF-CtBPdependent metabolic regulation of chromatin structure. Nat Neurosci. (2006) 9:1382-7. doi: $10.1038 / \mathrm{nn} 1791$

125. Kossoff E, Wang HS. Dietary therapies for epilepsy. Biomed J. (2013) 36:28. doi: $10.4103 / 2319-4170.107152$

126. Stafstrom CE, Ockuly JC, Murphree L, Valley MT, Roopra A, Sutula TP. Anticonvulsant and antiepileptic actions of 2-deoxy-D-glucose in epilepsy models. Ann Neurol. (2009) 65:435-47. doi: 10.1002/ana. 21603

127. Yudkoff M, Daikhin Y, Nissim I, Lazarow A, Nissim I. Ketogenic diet, amino acid metabolism, and seizure control. J Neurosci Res. (2001) 66:93140. doi: 10.1002/jnr.10083

128. Yudkoff M, Daikhin Y, Nissim I, Horyn O, Lazarow A, Luhovyy B, et al. Response of brain amino acid metabolism to ketosis. Neurochem Int. (2005) 47:119-28. doi: 10.1016/j.neuint.2005.04.014

129. Yudkoff M, Daikhin Y, Horyn O, Nissim I, Nissim I. Ketosis and brain handling of glutamate, glutamine, and GABA. Epilepsia. (2008) 49:735. doi: 10.1111/j.1528-1167.2008.01841.x

130. Juge N, Gray JA, Omote H, Miyaji T, Inoue T, Hara C, et al. Metabolic control of vesicular glutamate transport and release. Neuron. (2010) 68:99112. doi: 10.1016/j.neuron.2010.09.002

131. Kaminski RM, Livingood MR, Rogawski MA. Allopregnanolone analogs that positively modulate GABA receptors protect against partial seizures 
induced by 6-Hz electrical stimulation in mice. Epilepsia. (2004) 45:864-67. doi: 10.1111/j.0013-9580.2004.04504.x

132. Nishimura T, Schwarzer C, Gasser E, Kato N, Vezzani A, Sperk G. Altered expression of GABAA and GABAB receptor subunit mRNAs in the hippocampus after kindling and electrically induced status epilepticus. Neuroscience. (2005) 134:691-704. doi: 10.1016/j.neuroscience.2005.04.013

133. Fuenzalida M, Espinoza C, Pérez MÁ, Tapia-Rojas C, Cuitino L, Brandan E, et al. Wnt signaling pathway improves central inhibitory synaptic transmission in a mouse model of Duchenne muscular dystrophy. Neurobiol Dis. (2016) 86:109-20. doi: 10.1016/j.nbd.2015.11.018

134. Cerpa W, Gambrill A, Inestrosa NC, Barria A. Regulation of NMDAreceptor synaptic transmission by Wnt signaling. J Neurosci. (2011) 31:946671. doi: 10.1523/JNEUROSCI.6311-10.2011

135. Chuang YC, Chang AY, Lin JW, Hsu SP, Chan SH. Mitochondrial dysfunction and ultrastructural damage in the hippocampus during kainic acid-induced status epilepticus in the rat. Epilepsia. (2004) 45:12029. doi: 10.1111/j.0013-9580.2004.18204.x

136. Waldbaum S, Patel M. Mitochondria, oxidative stress, and temporal lobe epilepsy. Epilepsy Res. (2010) 88:23-45. doi: 10.1016/j.eplepsyres.2009.09.020

137. Houser CR. Granule cell dispersion in the dentate gyrus of humans with temporal lobe epilepsy. Brain Res. (1990) 535:195-204. doi: 10.1016/0006-8993(90)91601-C

138. El Bahh B, Lespinet V, Lurton D, Coussemacq M, Le Gal La Salle G, Rougier A. Correlations between granule cell dispersion, mossy fiber sprouting, and hippocampal cell loss in temporal lobe epilepsy. Epilepsia. (1999) 40:1393401. doi: 10.1111/j.1528-1157.1999.tb02011.x

139. Sullivan PG, Rippy NA, Dorenbos K, Concepcion RC, Agarwal AK, Rho JM. The ketogenic diet increases mitochondrial uncoupling protein levels and activity. Ann Neurol. (2004) 55:576-80. doi: 10.1002/ana.20062

140. Rubio C, Rubio-Osornio M, Retana-Marquez S, Lopez M, Custodio V, Paz C. In vivo experimental models of epilepsy. Cent Nerv Syst Agents Med Chem. (2010) 10:298-309. doi: 10.2174/187152410793429746

141. Palmer S, Towne MC, Pearl PL, Pelletier RC, Genetti CA, Shi J, et al. SLC6A1 mutation and ketogenic diet in epilepsy with myoclonic-atonic seizures. Pediatr Neurol. (2016) 64:77-9. doi: 10.1016/j.pediatrneurol.2016.07.012

142. López-Doménech G, Serrat R, Mirra S, D’Aniello S, Somorjai I, Abad A, et al. The Eutherian Armcx genes regulate mitochondrial trafficking in neurons and interact with Miro and Trak2. Nat Commun. (2012) 3:112. doi: $10.1038 /$ ncomms 1829

143. Yang H, Shan W, Zhu F, Wu J, Wang Q. Ketone bodies in neurological diseases: focus on neuroprotection and underlying mechanisms. Front Neurol. (2019) 10:585. doi: 10.3389/fneur.2019.00585

144. Jarrett SG, Milder JB, Liang LP, Patel M. The ketogenic diet increases mitochondrial glutathione levels. J Neurochem. (2008) 106:1044-51. doi: 10.1111/j.1471-4159.2008.05460.x

145. Kim DY, Davis LM, Sullivan PG, Maalouf M, Simeone TA, van Brederode J, et al. Ketone bodies are protective against oxidative stress in neocortical neurons. $J$ Neurochem. (2007) 101:1316-26. doi: 10.1111/j.1471-4159.2007.04483.x

146. Noma A. ATP-regulated K+ channels in cardiac muscle. Nature. (1983) 305:147-8. doi: 10.1038/305147a0

147. Nakazawa M, Kodama S, Matsuo T. Effects of ketogenic diet on electroconvulsive threshold and brain contents of adenosine nucleotides. Brain Dev. (1983) 5:375-80. doi: 10.1016/S0387-7604(83)80042-4

148. Nylen K, Velazquez JL, Sayed V, Gibson KM, Burnham WM, Snead OC 3rd. The effects of a ketogenic diet on ATP concentrations and the number of hippocampal mitochondria in Aldh5al(-/-) mice. Biochim Biophys Acta. (2009) 1790:208-12. doi: 10.1016/j.bbagen.2008.12.005
149. DeVivo DC, Leckie MP, Ferrendelli JS, McDougal DBJr. Chronic ketosis and cerebral metabolism. Ann, Neurol. (1978) 3:331-7. doi: 10.1002/ana.410030410

150. Karschin C, Ecke C, Ashcroft FM, Karschin A. Overlapping distribution of K(ATP) channel-forming Kir6.2 subunit and the sulfonylurea receptor SUR1 in rodent brain. FEBS Lett. (1997) 401:59-64. doi: 10.1016/S0014-5793(96)01438-X

151. Dunn-Meynell AA, Rawson NE, Levin BE. Distribution and phenotype of neurons containing the ATP-sensitive $\mathrm{K}+$ channel in rat brain. Brain Res. (1998) 814:41-54. doi: 10.1016/S0006-8993(98)00956-1

152. Zawar C, Plant TD, Schirra C, Konnerth A, Neumcke B. Cell-type specific expression of ATP-sensitive potassium channels in the rat hippocampus. $J$ Physiol. (1999) 514:327-41.

153. Pierrefiche O, Bischoff AM, Richter DW. ATP-sensitive K+ channels are functional in expiratory neurones of normoxic cats. J Physiol. (1996) 494:399-409. doi: 10.1113/jphysiol.1996.sp021501

154. Allen TGJ, Brown DA. Modulation of the excitability of cholinergic basal forebrain neurones by KATP channels. J Physiol. (2004) 554:35370. doi: 10.1113/jphysiol.2003.055889

155. Ikematsu N, Dallas ML, Ross FA, Lewis RW, Rafferty JN, David JA, et al. Phosphorylation of the voltage-gated potassium channel Kv2.1 by AMPactivated protein kinase regulates membrane excitability. Proc Natl Acad Sci USA. (2011) 108:18132-7. doi: 10.1073/pnas.1106201108

156. Tanner GR, Lutas A, Martínez-François JR, Yellen G. Single KATP channel opening in response to action potential firing in mouse dentate granule neurons. J Neurosci. (2011) 31:868996. doi: 10.1523/JNEUROSCI.5951-10.2011

157. Ashmore J, Olsen H, Sørensen N, Thrasivoulou C, Ahmed A. Wnts control membrane potential in mammalian cancer cells. J Physiol. (2019) 597:5899914. doi: 10.1113/JP278661

158. Tetsu O, McCormick F. $\beta$-catenin regulates expression of cyclin D1 in colon carcinoma cells. Nature. (1999) 398:422-6. doi: 10.1038/18884

159. Kramps $\mathrm{T}$, Peter $\mathrm{O}$, Brunner E, et al. Wnt/wingless signaling requires BCL9/legless-mediated recruitment of pygopus to the nuclear beta-cateninTCF complex. Cell. (2002) 109:47-60. doi: 10.1016/S0092-8674(02)00679-7

160. Masino SA, Li T, Theofilas P, Sandau US, Ruskin DN, Fredholm BB, et al. A ketogenic diet suppresses seizures in mice through adenosine A 1 receptors. J Clin Invest. (2011) 121:2679-83. doi: 10.1172/JCI57813

161. Lusardi TA, Akula KK, Coffman SQ, Ruskin DN, Masino SA, Boison D. Ketogenic diet prevents epileptogenesis and disease progression in adult mice and rats. Neuropharmacology. (2015) 99:500-9. doi: 10.1016/j.neuropharm.2015.08.007

162. Yang Q, Guo $M$, Wang $\mathrm{X}$, Zhao $\mathrm{Y}$, Zhao Q, Ding H, et al. Ischemic preconditioning with a ketogenic diet improves brain ischemic tolerance through increased extracellular adenosine levels and hypoxia-inducible factors. Brain Res. (2017) 1667:11-8. doi: 10.1016/j.brainres.2017.04.010

Conflict of Interest: The authors declare that the research was conducted in the absence of any commercial or financial relationships that could be construed as a potential conflict of interest.

Copyright $\odot 2020$ Rubio, Luna, Rosiles and Rubio-Osornio. This is an open-access article distributed under the terms of the Creative Commons Attribution License (CC $B Y)$. The use, distribution or reproduction in other forums is permitted, provided the original author(s) and the copyright owner(s) are credited and that the original publication in this journal is cited, in accordance with accepted academic practice. No use, distribution or reproduction is permitted which does not comply with these terms. 